\title{
Why do microorganisms produce rhamnolipids?
}

\author{
Lukasz Chrzanowski • Lukasz Lawniczak • \\ Katarzyna Czaczyk
}

Received: 18 March 2011/Accepted: 25 July 2011/Published online: 9 August 2011

(c) The Author(s) 2011. This article is published with open access at Springerlink.com

\begin{abstract}
We review the environmental role of rhamnolipids in terms of microbial life and activity. A large number of previous research supports the idea that these glycolipids mediate the uptake of hydrophobic substrates by bacterial cells. This feature might be of highest priority for bioremediation of spilled hydrocarbons. However, current evidence confirms that rhamnolipids primarily play a role in surface-associated modes of bacterial motility and are involved in biofilm development. This might be an explanation why no direct pattern of hydrocarbon degradation was often observed after rhamnolipids supplementation. This review gives insight into the current state of knowledge on how rhamnolipids operate in the microbial world.
\end{abstract}

Keywords Bacterial motility · Biodegradation · Biofilm · Biosurfactant $\cdot$ Cell surface hydrophobicity $\cdot$ Pseudomonas aeruginosa $\cdot$ Rhamnolipids

\section{Introduction}

Rhamnolipids are surface-active glycolipids of microbial origin, which have been extensively studied by numerous scientists all over the world (Fig. 1).

\section{Ł. Chrzanowski $(\bowtie) \cdot$ Ł. Ławniczak}

Institute of Chemical Technology and Engineering, Poznan

University of Technology, Pl. M. Skłodowskiej-Curie 2,

60-965 Poznan, Poland

e-mail: lucaschrz@gmx.de

K. Czaczyk

Department of Biotechnology and Food Microbiology, Poznan

University of Life Sciences, Wojska Polskiego 48,

60-627 Poznan, Poland
Several studies dedicated to this topic can be found, which mainly focus on rhamnolipid biosynthesis and isolation of new congeners and analytical studies concerning their chemical structures (Górna et al. 2011; ZgołaGrześkowiak and Kaczorek 2011), determination of their physico-chemical properties, especially in terms of surface activity, and potential applications (Maier and SoberónChávez 2000; Soberón-Chávez 2004; Nitschke et al. 2005; Soberón-Cháves et al. 2005; Abdel-Mawgoud et al. 2010). Several important functions of these biosurfactants were uncovered, but the reason and mechanics behind their production still remained unclear.

Environmental microbiologists speculated that the secretion of rhamnolipids is mainly a part of a naturally developed mechanism for improved substrate uptake. The potential use of biosurfactants in bioremediation of petroleum contamination has attracted a lot of attention (Oberbremer et al. 1990; Finnerty 1994). Additionally, the use of rhamnolipids brought about several advantages compared to synthetic surfactants (Lang and Wullbrandt 1999), such as: low critical micelle concentration values (ranging from 75 to $150 \mathrm{mg} / \mathrm{L}$; Wang et al. 2007, Chrzanowski et al. 2009c), the possibility of producing biosurfactants in situ, low environmental burden, high biodegradability and a high solubilization efficiency. Since the low solubility of petroleum hydrocarbons limited their bioavailability, it was expected that surfactant-induced solubilization would result in an enhanced biodegradation process (Miller 1995). In this concept, rhamnolipids were supposed to play the role of a mediator, which connected the hydrophilic microorganisms living in the environment with water-insoluble hydrophobic hydrocarbons. Alternatively, the modification of microbial cell surface properties by rhamnolipids would also lead to an increased contact area between the cells and carbon source (Zhang and Miller 1995). Promising 
Fig. 1 Important events and discoveries in the field of rhamnolipids

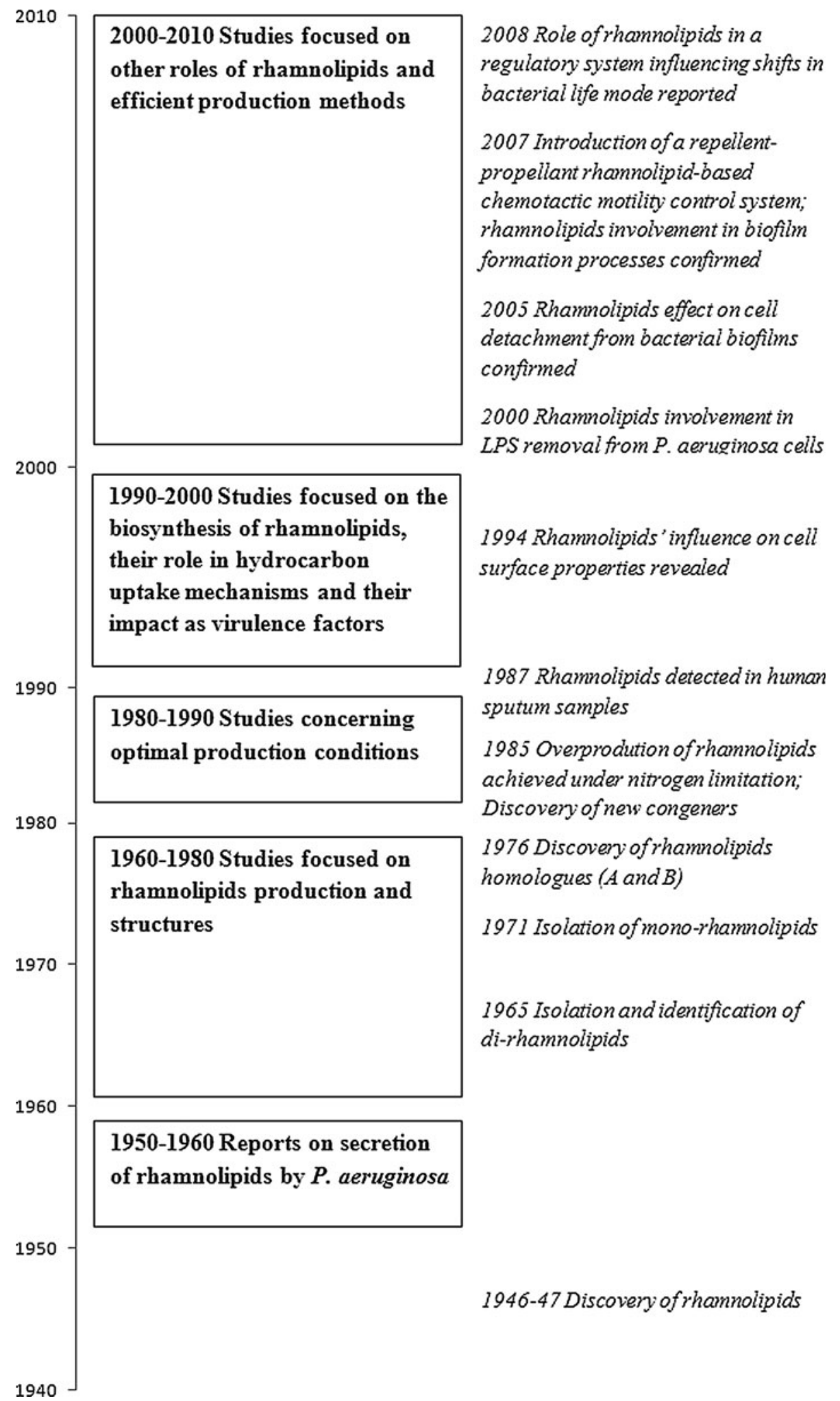

results were especially anticipated for polycyclic aromatic hydrocarbons $(\mathrm{PAH})$, which are considered as dangerous and hard-to-remove environmental pollutants (Déziel et al. 1996; Makkar and Rockne 2003; Fernández-Luqueño et al.
2011). Although some scientists reported positive effects after the addition of rhamnolipids (Zhang and Miller 1992), a lack of influence or even a negative effect of biosurfactant supplementation was observed just as frequently 
(Humphries et al. 1986; Falatko and Novak 1992; Owsianiak et al. 2009b; Chrzanowski et al. 2011).

However, the way of perceiving the role of biosurfactants in the functioning of microorganisms is diametrically changing in the light of the most recent studies concerning this topic (Caiazza et al. 2005; Verstraeten et al. 2008). With this in mind we will try to provide the most actual answer to the question: why do microorganisms produce rhamnolipids?

\section{Rhamnolipids in bioremediation of petroleum contaminants}

Influence of rhamnolipids on the solubility of hydrophobic hydrocarbons: initial concepts during laboratory studies

Microbial ability to produce biosurfactants during growth on hydrophobic substrates was very interesting for many scientists. The bioavailability of contaminants in the natural environment is one of the key factors limiting the progress of biodegradation processes (Volkering et al. 1998). The secretion of rhamnolipids would lead to the solubilization of hydrophobic compounds, which in turn contributed to a stimulation of biodegradation processes (Hisatsuka et al. 1971). It was often considered as an integral trait of microorganisms capable of biodegrading petroleum hydrocarbons. That is why some researchers directly connected the lack of genes responsible for rhamnolipids synthesis with the inability to grow on hydrophobic carbon sources, such as $n$-alkanes (Koch et al. 1991; Ochsner et al. 1994).

The ability to produce biosurfactants and change the interfacial tension was accepted as a potential mechanism for enhancing the transfer of hydrophobic substrates (Boulton and Ratledge 1984; Singer and Finnerty 1984). Solubilization of compounds from the oil phase and their transport into the water phase would exclude diffusion as a factor limiting the progress of biodegradation processes (Hommel 1994). The rhamnolipids-enhanced bioremediation concept became popular and numerous attempts were made to increase the bioavailability of hydrophobic substrates by biosurfactant supplementation during biodegradation tests. Zhang and Miller (1994) reported that the addition of rhamnolipids at $300 \mathrm{mg} / \mathrm{L}$ stimulated the biodegradation of octadecane. In some other experiments carried out by the same authors, rhamnolipids increased biodegradation of hexadecane for some species and inhibited the biodegradation of octadecane for other (Zhang and Miller 1995). At that time it was also observed that the addition of rhamnolipids led to a notable enhancement of the degradation efficiency for species which were unable to synthesize their own biosurfactant.

Due to numerous inconsistent reports regarding the effect of rhamnolipids on biodegradation efficiency, researchers started to thoroughly investigate not only the interactions between rhamnolipids and contaminants, but also the influence of this biosurfactant on the microorganisms.

Rhamnolipid-induced changes in microbial surface properties: parallel uptake mechanism

During their research Zhang and Miller (1994, 1995) also observed that the addition of biosurfactants contributed to changes in the cell surface hydrophobicity ( $\mathrm{CSH}$ ) of the studied bacterial species. This discovery led to new insights regarding microbial activity during the biodegradation process. At that time, the pursuit of simple correlations between the degrading microorganisms, rhamnolipids and hydrophobic substrates ended and the search for a more complex and multilevel theory started. In order to find answers to the questions at hand, subsequent experiments focused on investigating the influence of rhamnolipids on the surface properties of various bacterial species in terms of biodegradation efficiency. Numerous attempts to analyse the complicated dependencies between biosurfactants, microorganisms and xenobiotics were made in order to find the optimal conditions for biodegradation (Noordman and Janssen 2002). Based on the experimental data and analysis of biodegradation kinetics during several experiments a different mechanism of substrate uptake by microorganisms was proposed: direct contact of microbial cells with the hydrophobic carbon source. Changes in microbial surface properties, hydrophobicity in particular, were connected with the mechanism of direct substrate uptake from the oil phase (Chrzanowski et al. 2009a). Such changes, induced as a result of adsorption of rhamnolipids or other surfactants on the cell surface, would make for an alternative method of overcoming the limiting factors in substrate transport (Chrzanowski et al. 2006b, 2009b).

The increase in biodegradation efficiency could therefore be caused by enhanced hydrocarbon solubilization or modifications of the external cell structures, which in both cases contributed to an easier contact between the cells and the carbon source (Hommel 1994; Zhang and Miller 1994; Kaczorek et al. 2008). This theory could be used to explain some of the above-mentioned inconsistencies, but the results of experiments carried out in this field were still far from being uniform. The later work suggests that the observed increase in the biodegradation efficiency may be the effect of both phenomena occurring simultaneously. Many studies confirm that direct uptake from oil phase as well as biosurfactant-mediated solubilization of 
hydrophobic substrates in the water phase take place during biodegradation of PAH (Bouchez et al. 1997).

In order to investigate the preferable substrate uptake mechanism, experiments were carried out with the use of over sixty bacterial strains isolated from soil with various concentrations of petroleum contamination (Bouchez-Naïtali et al. 1999). The results obtained suggest that none of the mechanisms seems to be dominating. Half of the strains studied exhibited direct uptake from the oil phase, while the other half used the mechanism based on the biosurfactant-induced transfer enhancement. It is worth noting that for some of the strains studied the authors observed a lack of connection between hydrophobicity, biosurfactant production efficiency and the type of carbon source. Very similar results were obtained after growth on hydrophobic hexadecane and hydrophilic glycerol. It was concluded that the environmental conditions in the microorganisms' natural habitat impact their specific carbon source uptake mechanisms. Expanding the area of the hydrocarbon liquid phase in a given environment would most likely lead to the emergence of strains focusing on the direct uptake of substrates from the oil phase. It has been reported that the mass transfer rate is at its peak when the microorganisms grow in the direct vicinity of the hydrocarbon droplet (Johnsen et al. 2005). As for the water-rich environment, it is generally expected that it will be dominated by hydrophilic species. Therefore the biosurfactant-based uptake mechanism should be more advantageous. However in such systems the process of contaminant emulsification is more likely than their solubilization. Many authors point out that biosurfactants are produced by both hydrophilic and hydrophobic strains, regardless of the carbon source type used (Arino et al. 1996; Cooper 1984; Guerra-Santos et al. 1984; Mata-Sandoval et al. 1999; Matsufuji et al. 1997; Parra et al. 1990), which may suggest that their role may transcend the initially set boundaries and depend strongly on the environmental conditions.

Evaluation of the rhamnolipids-supplemented biodegradation theory in practice: getting closer to environmental conditions

The number of reports suggesting that efficient biodegradation processes occur without the presence of biosurfactants was growing. For example, in 2004 it was observed that the production of biosurfactants was completely unconnected with the biodegradation efficiency of hydrophobic substrates such as PAH (Johnsen and Karlson 2004). This may explain why only a limited number of experiments succeeded in finding a correlation between cell hydrophobicity and biodegradation efficiency (Chrzanowski et al. 2008; Obuekwe et al. 2007, 2008). However, at this point the studies entered a brand new environmental dimension. It was observed that although single strains can serve as an easy-to-use material for model studies, the attempts to apply the regularities observed during laboratory studies in field conditions mostly ended in failures, especially for the terrestrial environment (Jain et al. 1992).

It is worth noting that no microorganism is a lone island and that the degradation processes taking place in the environment are carried out by specialized groups of microorganisms called consortia or at least by mixed cultures. Currently there is a limited number of studies dedicated to investigating the influence of rhamnolipids or strains capable of their production on environmental consortia. However it has been reported that the addition of microorganisms with the ability to synthesize rhamnolipids did not affect the biodegradation of petroleum hydrocarbons in a terrestrial environment (Jain et al. 1992). This was most likely caused by difficulties during the adaptation to a new environment.

Many recent experiments showed both positive and negative effects of biosurfactant supplementation on the biodegradation of hydrophobic substrates by species isolated from the environment (Owsianiak et al. 2009a). Studies concerning the influence of rhamnolipids on diesel oil biodegradation efficiency by 218 environmental consortia point out that the addition of the biosurfactants equally increased, decreased and had no effect on the progress of degradation processes (Owsianiak et al. 2009b). A complete lack of correlation between the cell surface hydrophobicity and diesel oil removal rate was also observed. Similar observations were reported in other studies (Chrzanowski et al. 2005, 2006a). This may lead to the conclusion that in most cases the addition of rhamnolipids is not a significant factor in terms of biodegradation efficiency.

At this point alternative concepts from previous years returned (Neu 1996). It has been concluded that biosurfactants may play a vital role in various processes (Chrzanowski et al. 2009c) and enhancing the substrate uptake mechanisms is most likely just one of the phenomena observed. The next years are filled with studies focused on analysing the function of rhamnolipids during microbial colonization processes, biofilm development and detachment or specific activity versus other organisms.

\section{Rhamnolipids in bacterial cell motility}

Reaching the limits: production of rhamnolipids under different starvation conditions

In the case of substrate limitation, two scenarios are likely to occur: microorganisms either develop new mechanisms 
for gaining substrates which were previously unavailable, or they migrate from their current position in search of better life conditions. Based on the concept of limited accessibility, it was initially considered that rhamnolipids are mainly used to enhance the bioavailability of potential hydrophobic carbon sources for hydrophilic microorganisms (Arino et al. 2008). However the secretion of products with a high molecular mass in order to obtain substrates with a low molecular mass seems to be unfounded in terms of cellular energy balance. The average molecular mass of rhamnolipids is at $650 \mathrm{~g} / \mathrm{mol}$ whereas the average molecular mass of potential substrates, for instance octadecane, is at $254 \mathrm{~g} / \mathrm{mol}$. In field conditions it is also highly doubtful that the rhamnolipids will simply 'fetch' a octadecane droplet to the cell upon secretion. Moreover, several studies focused on evaluating the bioavailability of hydrocarbons in surfactant-supplemented samples suggest that compounds entrapped in micelles are not accessible for microorganisms. This fact was mainly proven for non-ionic surfactants (Dai et al. 2010; Wang 2011), however recently similar results have been reported for rhamnolipids (Chrzanowski et al. 2011; Zeng et al. 2011). It is more plausible that the presence of biosurfactants may lead to flushing out potential carbon sources from the vicinity of the cells. This simple fact may suggest that the possibility of microorganisms producing rhamnolipids for the sole purpose of obtaining carbon sources is rather low. Besides, in a heavily petroleum-contaminated environment which is rich in hydrocarbons, the depletion of nutrients is considered to be a far more important issue (Prince 2005). That is why often an initially rapid growth of hydrocarbon degraders is followed by a drop of biodegradation efficiency due to depletion of nitrogen and phosphorus sources at the contaminated site. This corresponds well with the early discoveries concerning the overproduction of rhamnolipids, which occurred mainly during nutrient limitation conditions. It was reported that the most effective production is reached when a limitation of nitrogen takes place (Guerra-Santos et al. 1986; Mulligan and Gibbs 1989; Desai and Banat 1997). In the stationary phase of growth, when the nitrogen sources are depleted, an accumulation of rhamnolipids in the growth medium occurs (Manresa et al. 1991). The overproduction of rhamnolipids was also observed under phosphorus limitation conditions (Mulligan et al. 1989). Taking this into account, perhaps it is more plausible that rhamnolipids are involved in the enhancement of microbial motility as means to relocate to nitrogen- and phosphorus-rich niches? Recent studies concerning cell motility provide strong evidence supporting this thesis (Tremblay et al. 2007; Verstraeten et al. 2008) (Fig. 2).
Basics behind bacterial motility: contribution of rhamnolipids

Studies concerning $P$. aeruginosa showed that bacterial cells are capable of three motility types: swimming with the help of flagella, twitching, which relies on type IV pili and most recently discovered multicellular swarming (Köhler et al. 2000; Déziel et al. 2003).

$P$. aeruginosa cells possess a singular polar flagellum, which allows them to swim in an aqueous environment. The flagella along with a chemoreceptor-based sensory system are used by the bacteria to rapidly respond to signals from the environment (Taguchi et al. 1997).

Twitching with the help of type IV pili is a surface motility (Whitchurch et al. 1991; Darzins 1994). It is considered that twitching occurs as a consequence of stretching and shrinking of the pili, which sets the cells in motion. The synthesis and formation of pili is controlled by many genes and the exact environmental conditions leading to their expression are still unknown (Hobbs et al. 1993). The pili are an important element of the cell structure, participating in virulence activity and attachment to abiotic surfaces (Hahn 1997; O'Toole and Kolter 1998).

However the newly-discovered swarming seems to be most complicated motility type. It is a form of an organized surface movement, which relies on cell elongation, presence of an adequate number of tendrils and cell-to-cell contact (Fraser and Hughes 1999). This phenomenon, which is exclusive for multicellular systems, embraces both cell integration and detachment i.e. during the colonization of a new environment. This type of motility is also considered by many researchers to be an integral part of processes such as formation of bacterial biofilms and infections caused by pathogenic microorganisms (Sharma and Anand 2002). Swarming cells are usually elongated and possess numerous tendrils. It was also suggested that some $P$. aeruginosa cells also need the type IV pili and rhamnolipids to successfully swarm (Köhler et al. 2000). The authors also concluded that initiating the swarming motility is tightly bound with nitrogen availability in the environment. Not only does this element influence the production of rhamnolipids, but it is also an important factor during the synthesis of pili (Goldflam and Rowe 1983; Ishimoto and Lory 1989). In a nitrogen-rich environment, the expression of genes responsible for the synthesis of pili is limited, which would also inactivate the swarming motility. Sensory-based decision-making system along with cell communication would play a crucial role in detecting environmental limiting factors and propagating proper responses - such as inducing rhamnolipid synthesis in a nutrient-deprived environment, which would allow the microorganisms to migrate into a new, nutrient-rich niche. 
Fig. 2 Conceptual pathway covering the studied topics concerning rhamnolipids

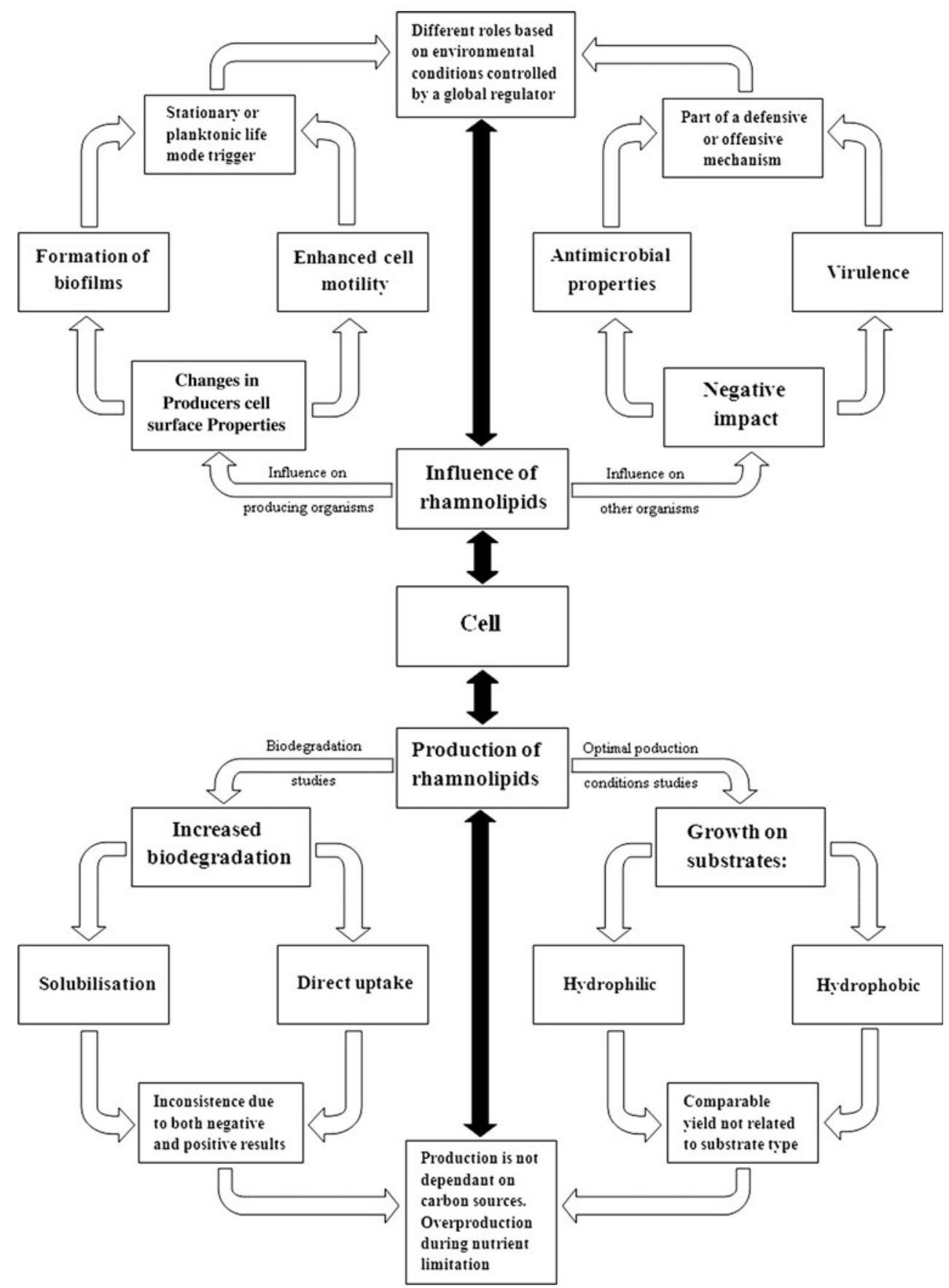

Rhamnolipids-based model for modulation of bacterial motility: chemotactic attractant-repellent system regulating swarming

The experiments carried out by Caiazza et al. (2005) and crucial results presented by Tremblay et al. (2007) provided unquestionable evidence regarding the connection between the presence of rhamnolipids and swarming motility. The first team of researchers suggested that rhamnolipids are responsible for the inhibition of cell motility, while the precursor compounds for their synthesis, 3-(3-hydroxyalkanoyloxy) alkanoic acids (HAAs), play the role of wetting agents. However, the studies performed by Tremblay et al. (2007) led to completely different conclusions, which were mostly caused by purity differences. The first team used a crude extract, which was a mixture of monorhamnolipids, dirhamnolipids and HAAs, while the second team investigated the influence of each separate component upon isolation and thorough purification. This allowed for obtaining very interesting results, which reported a chemotaxis-based system with two competitive effects induced by dirhamnolipids and HAAs. The authors 
concluded that dirhamnolipids serve as attractants which are recognized by bacterial swarmers and HAAs play the role of strong repellents. Both compounds also contribute to tendril formation, with dirhamnolipids promoting and HAAs inhibiting the process. Monorhamnolipids mainly act as wetting agents responsible for enhancing the transport by decreasing surface tension and do not play a major role in modulating swarming motility. Based on the experiments concerning diffusion kinetics, the authors developed a model describing the chemotactic stimulation of cell motility at regulatory level. According to this concept, dirhamnolipids spread much faster, which enables cell attraction. The authors also state that HAAs are a much stronger signal for the bacterial cells, therefore their presence, even at relatively low levels, might have caused the crude extract used by Caiazza et al. (2005) to exhibit swarming motility inhibition. The fact that the dirhamnolipids/HAA chemotactic system does not influence swimming motility was another major discovery. This led to a conclusion that cell motility type is not only connected with cell morphology, but also with various regulatory mechanisms.

\section{Influence of rhamnolipids during biofilm formation, maturation and detachment}

The more the merrier: rhamnolipids in development and maintenance of bacterial biofilms

Many microorganisms are capable of existing in two diametrically different modes: planktonic and in a form of multicellular communities, attached to various surfaces in a form of biofilms. However, among all the currently known microbes, the species which exist purely in planktonic mode are rather rare. In most cases this growth mode is just an intermediate step between cell detachment from mature biofilms and colonization of new niches (Costerton et al. 1999). The fact that microorganisms prefer living in biofilms situated on the interfacial boundary rather than struggling against all difficulties by themselves has been well known (Meadows 1971). The researches carried out report that growth in biofilms brings about several advantages like increased resistance to antibiotics (Costerton et al. 1999; Stewart 2002) and production of defensive substances (Friedman and Kolter 2004). Many researchers also suggest that the biofilm structure enhances the metabolic cooperation between the cells (Shapiro 1998) and intensifies both intracellular communication and horizontal gene transfer processes (Hausner and Wuertz 1999; Parsek and Greenberg 2000), which leads to increased genetic diversity and as a consequence improves the survival odds for microorganisms.
Based on the experiments performed and thorough investigation, a general concept describing the respective steps of bacterial biofilm formation was developed (O'Toole and Kolter 1998; Sauer et al. 2002). Upon attachment to solid or liquid surfaces, the microorganisms form a cellular monolayer covering a given area. The monolayer grows and transforms into a mature biofilm through cell growth and aggregation. Initially only microcolonies emerge, which afterwards form macrocolonies safely growing in a matrix created by exopolysaccharides and other extracellular polymeric compounds (EspinosaUrgel et al. 2000; Girón et al. 2002; Myszka et al. 2007; Czaczyk et al. 2008; Myszka and Czaczyk 2009). Mutual efforts of the microbial community communicating through quorum-sensing were also described (Parsek and Greenberg 2000). It was also pointed out that no complex structures were observed in biofilms created by mutants unable to communicate with other cells. Successive studies confirm that rhamnolipids play an important role during the first steps of biofilm creation, during cell attachment and when microcolonies emerge (Lequette and Greenberg 2005; Pamp and Tolker-Nielsen 2007).

However, the influence of rhamnolipids on the development of bacterial biofilms went beyond the primary stages. Experiments investigating the ability of $P$. aeruginosa cells to efficiently colonize body implants and live tissue provided evidence that some microorganisms tend to form biofilms with a strictly defined structure in an environment with a high nutrient circulation (O'Toole et al. 2000; Davey and O'Toole 2000). Bacterial cells are embedded in a matrix created from extracellular secretions and afterwards several colonies are created, forming filaments and growing mushroom-like tendrils into the surrounding environment, which are divided by transport channels. The formation and retaining of such a structure is crucial in terms of nutrient, oxygen and metabolite transportation (O'Toole et al. 2000). The results obtained by Davey et al. (2003) suggest that rhamnolipids are responsible for maintaining the transport channels and directly influence biofilm structure. Furthermore they are responsible for the before-mentioned changes in the mature biofilm structure, namely the creation of mushroom-like filaments (Pamp and Tolker-Nielsen 2007). It was also concluded that rhamnolipids may be used to exclude other, invasive species from the biofilm structure (Espinosa-Urgel 2003). Such a strategy allows the microbial community to maintain its uniform structure and exclusiveness over a given niche.

When things get tight: involvement of rhamnolipids in cell detachment and 'central hollowing'

Even though the advantages of living in a biofilm are apparent, there are also several limitations and disadvantages 
which must be considered. The sole process of creating the matrix is undoubtedly an exhausting process and disturbances in distribution through transport channels may potentially lead to growth limitations and decrease the biosynthesis efficiency (Hassett et al. 1999). Nutrient exhaustion is most likely the worst-case scenario for bacterial cells living in a biofilm. Such a limiting factor would be a serious problem for cells entrapped in a biopolymer matrix (Whiteley et al. 2001). Therefore a mechanism which would allow the cells with limited motility to shift into planktonic mode is needed, as this would provide them with an 'emergency exit' in times of trouble. This process, called 'cell detachment', has been the topic of many studies during the last decade. As opposed to cell flushing, where bacterial cells are physically removed from the environment through the activity of strong hydrodynamic forces, the process of selfinduced separation is caused by unfriendly environmental conditions (Stoodley et al. 2002; Thormann et al. 2005). The ability to freely shift from one growth mode to another allows the microorganisms to effectively and rapidly adapt to changes in their environment (Déziel et al. 2001). Cell detachment is also a key factor in terms of pathogenic activity, where the separation leads to the emergence of mobile cells and cell agglomerates, which successively colonize tissues and spread the infection. Numerous clinical cases initiated by cells detached from mature biofilms have been discovered and described (Bergmans et al. 1998; Parsek and Singh 2003). Many researchers consider the cell detachment process to be complicated, because various different separation mechanisms were observed even among a single strain.

After investigating several $P$. aeruginosa biofilms, it was observed that detachment may involve single cells, bacterial agglomerates or even whole colonies (Stoodley et al. 2001). In favorable conditions only a limited number of cells detach from natural biofilms. On rare occasions a bigger bacterial cluster may separate after a relatively long growth period. This kinds of occurrences exhibit a high variety in terms of time, biofilm area from which they detach and separation mechanism. The formation of internal cavities in a mature biofilm was very interesting, as it distorted its structure and caused a major release of bacterial cells. This process is called 'central hollowing' (Sauer et al. 2002; Hunt et al. 2004). Numerous researchers focused on analysing changes induced throughout biofilm during rapid and violent environmental changes, which allowed for a determination of several factors initiating biofilm detachment (Webb et al. 2003; Hunt et al. 2004; Thormann et al. 2005). At that time several studies also reported the influence of rhamnolipids on biofilm fracturing and distortion (Schooling et al. 2004; Irie et al. 2005).

A clear connection was found when a $P$. aeruginosa strain exhibiting a tendency to spontaneously detach cells from the biofilm was isolated (Boles et al. 2004, 2005). This unique feat enabled the authors to concentrate purely on the separation mechanisms. The authors speculated that several mechanisms occur simultaneously during biofilm detachment: the biodegradation of the biopolymer matrix is followed by severe physiological shifts and changes in motility patterns which would allow the cells to quickly assume the planktonic growth mode. It was concluded that the presence of biosurfactants was needed to maintain the ability to excessively detach bacterial cells and led to an intensification of physiological changes towards the planktonic phenotype. These results were affirmed not only for the studied isolate, but also for biofilms formed by wild strains. Based on several observations, it was proposed that the signals responsible for invoking 'central hollowing' were strongest inside the biofilm structure, which would cause the activation of separation mechanisms (Allison et al. 1998). Two significant factors involved in the initiation of this process were determined: accumulation of substances which serve as separation signals (such as metabolic end products) and nutrient deficiency (Hunt et al. 2004). It is worth noticing that both of these factors influence the expression of genes responsible for rhamnolipid biosynthesis.

It was also suggested that another mechanism enabling 'central hollowing' may exist (Boles et al. 2005). Based on the experiments carried out, it was concluded that cells involved in the creation of biofilm exhibit different susceptibility to factors initiating separation, depending in their position. Trials performed with the use of externally added rhamnolipids and sodium dodecylbenzenesulphonate confirmed that the centre of the biofilm is much more susceptible to detachment processes compared to biofilm peripheries. The authors propose that the observed differences may be a consequence of several factors, such as starving conditions, biopolymer matrix structure, composition of local adhesive compounds or other phenotypic differences among the cells. The existence of populations involving cells with different properties within a single biofilm would also explain the presence of transport channels. Rhamnolipids secreted by peripheral bacteria would induce the separation of cells from the biofilm centre, creating transfer channels, which in turn allow for a regulation of nutrient transportation throughout the whole biofilm. However the authors point out that both environmentally induced and different susceptibility mechanisms may occur simultaneously.

Two sides of rhamnolipids united: combining cell motility and biofilm formation

Therefore not only do rhamnolipids stimulate the coordinated movement of multicellular structures, but they also 
play a major role during the regulation of cell detachment in a mature biofilm. During the stationary growth mode these biosurfactants may act as a protective agent against microbial intruders of leucocytes and in the planktonic mode they enhance pathogenic activity. After an analysis of the 'central hollowing' phenomenon and a thorough observation of the 'cell detachment' process it is easy to find several similarities between these two occurrences. In the previously mentioned experiment Tremblay et al. (2007) suggested that swarming motility needs a well organized and multicellular structure, therefore it may be akin to processes taking place during the emergence and maturing of bacterial biofilms. It was reported that the formation of mushroom-like filaments on the surface of mature biofilms is a direct consequence of bacterial motility (Pamp and Tolker-Nielsen 2007). However at the moment it is hard to determine which type of motility is involved, as rhamnolipids may induce twitching as well as swarming. The authors conclude that because of a broad range of potential possibilities, there must be a system regulating the actual role of rhamnolipids, which is based on expression and activation of adequate genes at a given moment. The detailed analysis of genes involved in the biosynthesis of rhamnolipids allowed the discovery of a complex network of connections between all the abovementioned phenomena and several other factors.

\section{Genetic mechanisms regulating the role rhamnolipids}

Genetic evidence for diversity of roles of rhamnolipids: connections and regulation mechanisms

$P$. aeruginosa cells showed that the biosynthesis of rhamnolipids is controlled by three genes: $r h l A, r h l B$ i $r h l C$ (Soberón-Cháves et al. 2005) and a quorum-sensing-based regulatory mechanism (Sauer et al. 2002). It was discovered that the first two genes responsible for the synthesis are encoded by the $\operatorname{rhlAB}$ operon induced by RhlR. RhlA is responsible for the synthesis of precursor compounds: HAAs (Déziel et al. 2003). The $r h l B$ gene is connected with rhamnosyltransferase, which catalyses the transfer of L-rhamnose deoxythymidine diphosphate (dTDP-L-rhamnose) molecules on HAA, thus forming monorhamnolipids (Ochsner et al. 1994). The last of the genes is most likely encoded by an operon located in the vicinity of the PA1131 gene. Several researchers speculate that this gene encodes a protein which is yet unknown and is also induced by RhlR (Roberts et al. 1967). RhlC is responsible for catalysing the addition of another rhamnose molecule, which yields dirhamnolipids (Rahim et al. 2001). A similar system with homologous genes was detected in other species capable of producing rhamnolipids (Dubeau et al. 2009).
The regulation of rhamnolipid biosynthesis is a complex and multilevel process. The expression of $\operatorname{rhl} B B$ depends on the sigma factor $\sigma^{\mathrm{S}}$ and quorum-sensing-based regulators: RhlR and LasR (transcriptional regulatory proteins) (Verstraeten et al. 2008). RhlR activity is induced by the presence of $\mathrm{N}$-acylhomoserine lactones (acyl-HSL) (Ochsner and Reiser 1995). Signaling compounds, such as acyl-HSL may be accumulated inside the biofilm structure. The overproduction of rhamnolipids observed by many researchers during nutrient limitation conditions proves that the activation of $\operatorname{rlh} A B$ gene is connected with starvation signals. After studying various $P$. aeruginosa strains, a new regulatory system at posttranscriptional level based on the activity of an RNA-binding protein RsmA was discovered (Heurlier et al. 2004). RsmA exhibits positive control over swarming motility and virulence, however it affects biofilm formation processes in a negative manner. Inactivation of quorum-sensing-based systems and limitation of polysaccharide production occurs as a consequence of $\mathrm{N}$-acyl-HSL level regulation. Two regulatory RNAs control the RsmA activity: RsmY and RsmZ. The detailed studies concerning this regulatory system led to discovery of two sensor kinases, RetS (which serves as an exopolysaccharide and type III secretion regulator) and LadS (lost adherence regulator). During experiments concerning the inactivations of RetS in $P$. aeruginosa cells, it was observed that such mutants displayed an increased tendency to form biofilms, while the ability to swarm was completely inactivated (Goodman et al. 2004, Ventre et al. 2006).

Very interesting results were also obtained during experiments with mutants lacking genes responsible for rhamnolipid synthesis. Inactivation of the rhlA gene caused an inhibition of swarming motility and reduced twitching motility, although it did not influence the ability of the cells to swim (Köhler et al. 2000; Pamp and Tolker-Nielsen 2007). P aeruginosa cells, which were unable to produce rhamnolipids, were more susceptible to phagocytosis and exhibited inhibited virulence (Van Gennip et al. 2009). It was pointed out that the inactivation of the same gene is connected with significant changes in the biofilm structure (Davey et al. 2003). The mutants were unable to form mushroom-like filaments, which are a characteristic trait of mature biofilms. Other researchers suggest that the disturbance in $\operatorname{rhl} A B$ gene expression is also connected with changes in cell detachment processes (Boles et al. 2005). Inactivation of genes responsible for rhamnolipid synthesis caused an inhibition of separation processes. However neither the external addition of rhamnolipids nor reactivation of gene expression allowed for a complete restart of the cell detachment processes. Separation from the biofilm seems to be strictly connected with rhamnolipid overproduction, biosynthesis of enzymes degrading the biopolymer 
Fig. 3 Decision-making system for bacterial life mode

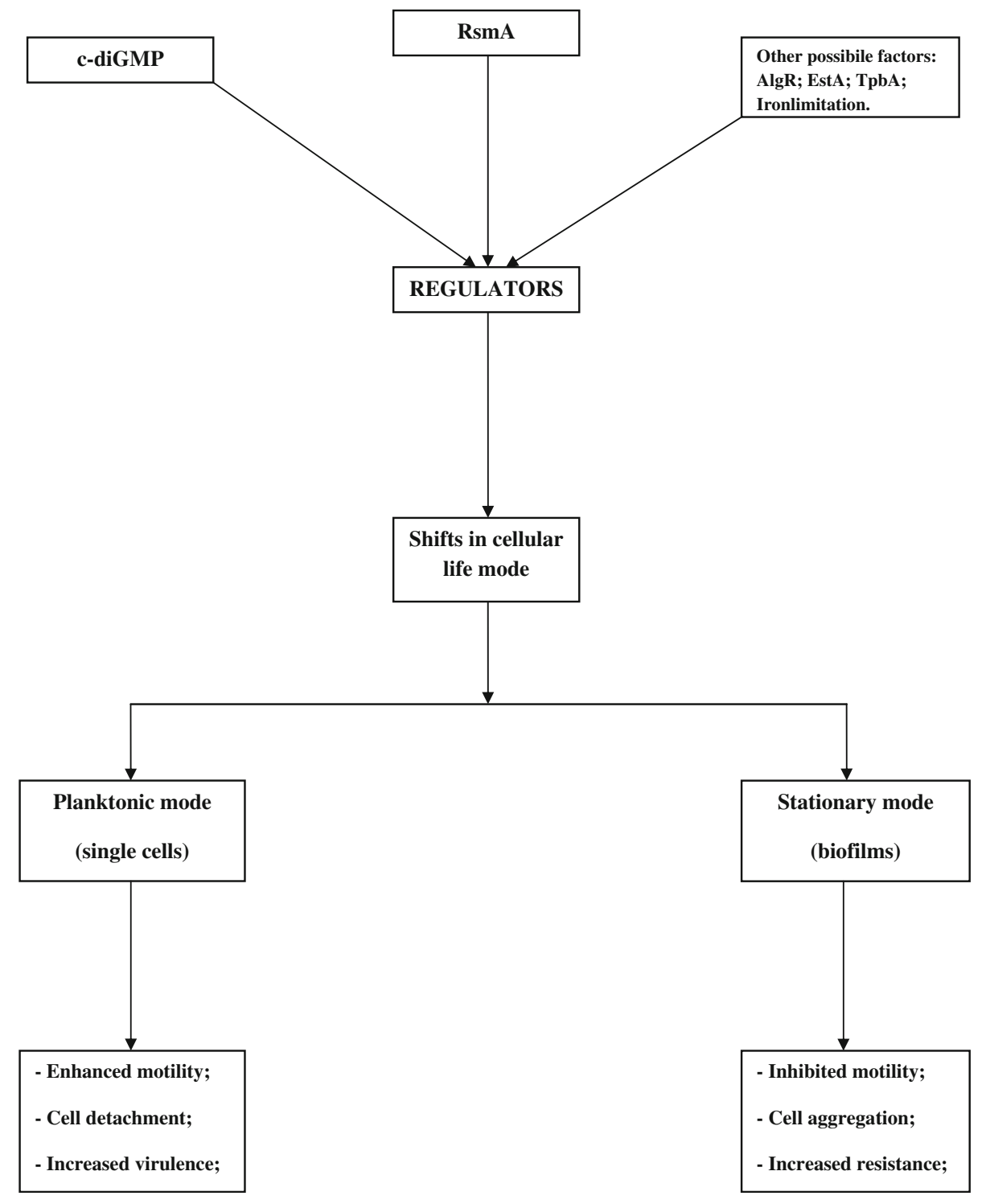

matrix and increased migration activity, which overall leads to a recovery of planktonic cell type phenotypic traits. These results may suggest the existence of a global regulatory factor, which coordinates cell activity during choices between a mobile and stationary lifestyle through rhamnolipid biosynthesis.

Quest for the Holy Grail: in search of the ultimate global regulator

It was concluded that the before-mentioned RsmA is one of such global regulatory factors (Verstraeten et al. 2008). It influences cell living mode by stimulating swarming motility and activating pathogenic behavior, while inhibiting biofilm formation processes. Another major regulator, which was recently discovered, is c-di-GMP — an intracellular signaling molecule (Jenal and Malone 2006; Wolfe and Visick 2008). In accordance with environmental signals, which directly influence the concentration of c-diGMP, the cells display various changes in behavior. Increased c-di-GMP biosynthesis contributes to an enhanced stability of multicellular agglomerates and reduces both cell motility and pathogenic activity. Currently 38 proteins have been discovered in $P$. aeruginosa cells which may function as sensory molecules and regulate the local and global concentration of c-di-GMP. Studies carried out with the use of $P$. aeruginosa PA14 strain led to the discovery of three significant enzymes regulating the aspects of motility and tendency to form bacterial biofilms: SadC, BifA and SadB (Verstraeten et al. 2008). SadC is a diguanylate cyclase responsible for the synthesis of c-di-GMP, most likely as a response to signals indicating cell-surface contact or shifts in medium viscosity (Merritt et al. 2007). BifA is a phosphoesterase, which allows for c-di-GMP 
regulation and signal intensity control (Kuchma et al. 2005). Finally, SadB is most likely involved in transferring the signal to pel and psl loci, where the genes regulating exopolysaccharide synthesis and flagellar functions are located. Interestingly, the results obtained by Hickman and Harwood (2008) also point out that the main regulator for expression of genes involved in flagellar function modulation $(\mathrm{FleQ})$ is capable of repressing the pel genes through changes in c-di-GMP concentration.

Two loci were discovered in $P$. aeruginosa cells which are responsible for expression level control and activity of GGDEF-domain and EAL-domain proteins (c-di-GMP concentration regulators). These two loci are wsp and sadSRA. Numerous studies dedicated to this field suggest that both signal conveying systems influence cellular behavior as a response to changing environmental factors. Disturbances in the range of $w s p$ loci cause increased cell aggregation and changes in cell morphology, as well as inhibited twitching and swimming motility (Hickman et al. 2005). The correct activity of the second system based on the sadSRA loci is required for a proper progress of biofilm maturation processes (Kulasekara et al. 2005; Kuchma et al. 2007). Through regulation of the c-di-GMP level, these two systems control cell motility, exopolysaccharide secretion and biofilm formation, which makes them a trigger between the mobile and stationary life modes.

Recent experiments conducted in order to find other key elements suggest that several other potential regulators may exist. Factors such as the regulatory protein AlgR, autotransporter esterase EstA and iron limitation were found to play a crucial role in modulating microbial behavior and decision-making processes (Morici et al. 2007; Wilhelm et al. 2007; Glick et al. 2010) (Fig. 3).

Simultaneously, these studies provide evidence that rhamnolipids are a vital part of the system, which hold reign over the domain of microorganisms. Since the mechanisms regulating the morphological changes occur not only for a single cell, but also for whole colonies, many recent studies are focused on investigating the complex interactions between environmental conditions, regulatory signal compounds and responses of the microbial community.

\section{Summary}

The results of several independent experiments have contributed to a better understanding of the multiple roles that rhamnolipids may play in the life of microorganisms. The specific biosurfactant function seems to be connected with environmental conditions and corresponding regulatory systems. The range of rhamnolipid functions covers solubilization, modification of surface properties, stimulation of bacterial motility, formation and disruption of biofilms, virulence and anti-microbial activity (Table 1).

The reason why microorganisms produce rhamnolipids seems to be a diverse topic. Although the wide range of functions covered by these compounds was initially the cause of some scientific inconsistencies, it may now be considered as a complex, yet uniform fusion of the

Table 1 Overview of studies focused on rhamnolipids and their main conclusions (the last 20 years)

\begin{tabular}{|c|c|c|c|c|}
\hline Category & Year & Outline & Main conclusions & Reference \\
\hline Bioremediation & 1990 & $\begin{array}{l}\text { Influence of rhamnolipids on the } \\
\text { biodegradation of a hydrocarbon mixture }\end{array}$ & $\begin{array}{l}\text { Rhamnolipids increased the biodegradation } \\
\text { efficiency and were degraded afterwards }\end{array}$ & $\begin{array}{l}\text { Oberbremer } \\
\text { et al. (1990) }\end{array}$ \\
\hline Bioremediation & 1991 & $\begin{array}{l}\text { Biodegradation of hexadecane by mutants } \\
\text { unable to produce rhamnolipids }\end{array}$ & $\begin{array}{l}\text { The inability to utilize hexadecane was observed } \\
\text { for mutants unable to produce rhamnolipids; } \\
\text { Addition of rhamnolipids restored the ability to } \\
\text { grow on alkanes }\end{array}$ & $\begin{array}{l}\text { Koch et al. } \\
\text { (1991) }\end{array}$ \\
\hline Bioremediation & 1992 & $\begin{array}{l}\text { Impact of biosurfactants produced by } \\
\text { microorganisms on the solubilization and } \\
\text { biodegradation of petroleum hydrocarbons }\end{array}$ & $\begin{array}{l}\text { Biosurfactants produced during growth on } \\
\text { glucose and vegetable oil inhibited } \\
\text { biodegradation processes; The influence of } \\
\text { biosurfactants may be limited due to possible } \\
\text { sorption in soil }\end{array}$ & $\begin{array}{l}\text { Falatko and } \\
\text { Novak } \\
(1992)\end{array}$ \\
\hline Bioremediation & 1992 & $\begin{array}{l}\text { Influence of biosurfactants or biosurfactant- } \\
\text { producing microorganisms addition on the } \\
\text { biodegradation of hydrocarbons in soil }\end{array}$ & $\begin{array}{l}\text { The presence of the biosurfactant increased the } \\
\text { biodegradacion efficiency of some } \\
\text { hydrocarbons, while the presence of producing } \\
\text { microorganisms had no effect }\end{array}$ & $\begin{array}{l}\text { Jain et al. } \\
\text { (1992) }\end{array}$ \\
\hline Bioremediation & 1992 & $\begin{array}{l}\text { Effect of rhamnolipids addition on dispersion } \\
\text { and biodegradation of octadecane }\end{array}$ & $\begin{array}{l}\text { The presence of rhamnolipids enhanced the } \\
\text { dispersion of octadecane and increased its } \\
\text { biodegradation efficiency }\end{array}$ & $\begin{array}{l}\text { Zhang and } \\
\text { Miller } \\
\text { (1992) }\end{array}$ \\
\hline
\end{tabular}


Table 1 continued

\begin{tabular}{lll}
\hline Category & Year & Outline \\
\hline Bioremediation & 1994 & $\begin{array}{l}\text { Influence of rhamnolipids on cell surface } \\
\text { hydrophobicity of bacterial cells during } \\
\text { octadecane biodegradation }\end{array}$
\end{tabular}

Bioremediation $1995 \begin{gathered}\text { Dirhamnolipids in the acid and methyl ester } \\ \text { form were used to increase the degradation } \\ \text { of hexadecane or octadecane }\end{gathered}$

Bioremediation 1999 Mechanisms of hexadecane uptake related to the rhamnolipids-biosynthesis

Bioremediation

2000 Comparison of hexadecane biodegradation efficiency carried out with the use of rhamnolipid producing and biosurfactantdeficient $P$. aeruginosa strains

Bioremediation

Bioremediation

2000 Effect of rhamnolipids on cellular surface properties

Influence of rhamnolipids on biodegradation of hydrophobic compounds

by $P$. aeruginosa strains

Bioremediation

Effect of rhamnolipids on cell hydrophobicity and biodegradation efficiency for yeast and bacteria

Bioremediation

2008 Influence of a rhamnolipid-producing $P$. aeruginosa strain on the biodegradation of PAHs by a bacterial community

Bioremediation

2008 Influence of rhamnolipids on surface properties and biodegradation potential of yeast and bacteria

Bioremediation

2009 Rhamnolipids decrease the toxicity of chlorinated phenols

Bioremediation

2009 Effect of rhamnolipids on the biodegradation of diesel and diesel-biodiesel blends carried out by a microbial consortium

Bioremediation

2009 Rhamnolipid-mediated biodegradation of diesel oil by soil isolated microbial consortia
Main conclusions

Reference

The presence of rhamnolipids increased the cell surface hydrophobicity of slow degrading species; Initial inhibition of octadecane biodegradation observed at low concentrations of rhamnolipids

The methyl ester form was more effective for increasing the degradation efficiency; The influence of rhamnolipids was dependant on the initial cell surface hydrophobocity

Half of the isolated strains utilized direct interfacial uptake mechanism. The other half was capable of producing rhamnolipids, which contributed mostly to a surfactant-mediated inferfacial uptake. Pure surfactant-mediated solubilization mechanism was rare among the isolates

Increased biodegradation efficiency was observed for the rhamnolipid producer; the biosurfactant increased the concentration of hexadecane in the water medium; In both cases the cell hydrophobicity increased

Rhamnolipids caused an overall loss in cellular fatty acid content due to release of lipopolysaccharide from the outer membrane

Rhamnolipids stimulated the uptake of hydrocarbons for some strains and had no effect on others; Different uptake mechanisms were suggested, which may be energydependant

The addition of rhamnolipids contributed to a general decrease of cell surface hydrophobicity and increase of hexadecane biodegradation efficiency

The presence of rhamnolipid-producers enhanced the PAH biodegradation efficiency, however the presence of rhamnolipids inhibited the growth of some species; The biosurfactants induced changes in cell surface properties

Rhamnolipids increased the cell surface hydrophobicity of the studied strains, which in turn resulted in enhanced biodegradation of hydrocarbons

Rhamnolipid micelles entrapped chlorophenol molecules decreasing their bioavailability and acute toxicity

The presence of the biosurfactant influenced the stability of fuel emulsions; rhamnolipids enhanced the biodegradation efficiency only of the blends with a low diesel content

The influence of rhamnolipids on the biodegradation efficiency of the microbial consortia included facilitation, inhibition and no effect at all; No correlation between the microbial cell surface hydrophobicity and degradation was found
Zhang and

Miller

(1994)

Zhang and Miller

(1995)

Bouchez-

Naïtali et al. (1999)

Beal and

Betts

(2000)

Al-Tahhan et al. (2000)

Noordman and Janssen (2002)

Chrzanowski et al. 2006b

Arino et al. (2008)

Kaczorek et al. (2008)

Chrzanowski et al.

(2009c)

Owsianiak et al. (2009a)

Owsianiak et al. (2009b) 
Table 1 continued

\begin{tabular}{|c|c|c|c|c|}
\hline Category & Year & Outline & Main conclusions & Reference \\
\hline Bioremediation & 2011 & $\begin{array}{l}\text { Effect of rhamnolipids on the biodegradation } \\
\text { of a model hydrocarbon rich effluent co- } \\
\text { contaminated with chlorophenols }\end{array}$ & $\begin{array}{l}\text { Interactions between rhamnolipids and } \\
\text { chlorophenols contributed to a decreased } \\
\text { toxicity; Possible absorption of chlorophenols } \\
\text { on the surface of surfactant aggregates }\end{array}$ & $\begin{array}{l}\text { Chrzanowski } \\
\text { et al. (2011) }\end{array}$ \\
\hline Microbial biofilms & 2003 & $\begin{array}{l}\text { Connection between production of } \\
\text { rhamnolipids and biofilm architecture }\end{array}$ & $\begin{array}{l}\text { Rhamnolipids are used to maintain non- } \\
\text { colonized channels throughout the whole } \\
\text { biofilm; The production is regulated through } \\
\text { intercellular interaction and communication }\end{array}$ & $\begin{array}{l}\text { Davey et al. } \\
\text { (2003) }\end{array}$ \\
\hline Microbial biofilms & 2003 & $\begin{array}{l}\text { Rhamnolipids as biosurfactants maintaining } \\
\text { the fluid channels in mature biofilms }\end{array}$ & $\begin{array}{l}\text { Rhamnolipids might also be a part of a defensive } \\
\text { mechanism, which prevents other } \\
\text { microorganisms from colonizing the channels }\end{array}$ & $\begin{array}{l}\text { Espinosa- } \\
\text { Urgel } \\
(2003)\end{array}$ \\
\hline Microbial biofilms & 2004 & $\begin{array}{l}\text { Involvement of rhamnolipids in biofilm } \\
\text { maintenance and cell detachment }\end{array}$ & $\begin{array}{l}\text { The addition of rhamnolipids to freshly } \\
\text { inoculated substrata inhibited biofilm } \\
\text { formation; Inflicting changes in the system } \\
\text { regulating rhamnolipid biosynthesis resulted in } \\
\text { increased biofilm formation trends }\end{array}$ & $\begin{array}{l}\text { Schooling } \\
\text { et al. (2004) }\end{array}$ \\
\hline Microbial biofilms & 2005 & $\begin{array}{l}\text { Rhamnolipids influence on cell detachment } \\
\text { in } P \text {. aeruginosa biofilms }\end{array}$ & $\begin{array}{l}\text { Rhamnolipids were required for cell detachment } \\
\text { in mature biofilms; the biosurfactant-based } \\
\text { mechanism involved the creation of cavities in } \\
\text { the centre of the biofilm structure }\end{array}$ & $\begin{array}{l}\text { Boles et al. } \\
\text { (2005) }\end{array}$ \\
\hline Microbial biofilms & 2005 & $\begin{array}{l}\text { Influence of rhamnolipids produced by } \\
P \text {. aeruginosa on biofilms of other } \\
\text { microbial species }\end{array}$ & $\begin{array}{l}\text { Rhamnolipids dispersed Bordetella } \\
\text { Bronchiseptica biofilms }\end{array}$ & $\begin{array}{l}\text { Irie et al. } \\
\quad(2005)\end{array}$ \\
\hline Microbial biofilms & 2005 & $\begin{array}{l}\text { Production of rhamnolipids in bacterial } \\
\text { biofilms }\end{array}$ & $\begin{array}{l}\text { Synthesis of rhamnolipids is an essential part of } \\
\text { biofilm maturation and the formation of } \\
\text { 'mushroom-like' structures }\end{array}$ & $\begin{array}{l}\text { Lequette and } \\
\text { Greenberg } \\
(2005)\end{array}$ \\
\hline Microbial biofilms & 2007 & $\begin{array}{l}\text { Influence of rhamnolipids on the formation, } \\
\text { development and maturation of bacterial } \\
\text { biofilms }\end{array}$ & $\begin{array}{l}\text { Rhamnolipids promoted formation of } \\
\text { microcolonies during the initial steps and } \\
\text { facilitated migration-dependant structural } \\
\text { development in the latter stages }\end{array}$ & $\begin{array}{l}\text { Pamp and } \\
\text { Tolker- } \\
\text { Nielsen } \\
(2007)\end{array}$ \\
\hline Microbial motility & 2000 & $\begin{array}{l}\text { Regulation of swarming motility } \\
\text { in } P \text {. aeruginosa cells }\end{array}$ & $\begin{array}{l}\text { Mutants with the inability to produce } \\
\text { rhamnolipids ( } r h l \text { gene deficiency) were unable } \\
\text { to successfully swarm; }\end{array}$ & $\begin{array}{l}\text { Köhler et al. } \\
\text { (2000) }\end{array}$ \\
\hline Microbial motility & 2003 & $\begin{array}{l}\text { Genetic expression of genes encoding the } \\
\text { rhamnolipid biosynthesis ability influence } \\
\text { swarming motility }\end{array}$ & $\begin{array}{l}\text { The expression of } r h l A \text { was required for } \\
\text { swarming motility; the use of ammonium as a } \\
\text { nitrogen source decreased } r h l A \text { expression and } \\
\text { inhibited swarming }\end{array}$ & $\begin{array}{l}\text { Déziel et al. } \\
\text { (2003) }\end{array}$ \\
\hline Microbial motility & 2005 & $\begin{array}{l}\text { Influence of rhamnolipids on swarming } \\
\text { motility patterns }\end{array}$ & $\begin{array}{l}\text { Microbial group behavior is connected with the } \\
\text { production and presence of rhamnolipids }\end{array}$ & $\begin{array}{l}\text { Caiazza et al. } \\
\text { (2005) }\end{array}$ \\
\hline Microbial motility & 2007 & $\begin{array}{l}\text { Influence of rhamnolipid congeners on } \\
\text { swarming motility }\end{array}$ & $\begin{array}{l}\text { A chemotactic attractant - repellent system was } \\
\text { discovered with dirhamnolipids as attractants, } \\
\text { hydroxyalkanoyloxy alkanoic acids as } \\
\text { repelants and monorhamnolipids as wetting } \\
\text { agents; the system only influenced swarming } \\
\text { cells and not swimming cells }\end{array}$ & $\begin{array}{l}\text { Tremblay } \\
\text { et al. (2007) }\end{array}$ \\
\hline Production & 1991 & $\begin{array}{l}\text { Rhamnolipids production kinetics under } \\
\text { different nitrogen regimes }\end{array}$ & $\begin{array}{l}\text { Production of rhamnolipids started at the end of } \\
\text { the exponential phase and the beginning of the } \\
\text { stationary phase, when nitrogen levels were } \\
\text { low; Rhamnolipid yield increased with the } \\
\text { increasing level of nitrogen }\end{array}$ & $\begin{array}{l}\text { Manresa et al. } \\
\text { (1991) }\end{array}$ \\
\hline Production & 1996 & $\begin{array}{l}\text { Production of rhamnolipids by } \\
P \text {. aeruginosa strains grown of different } \\
\text { carbon sources }\end{array}$ & $\begin{array}{l}\text { Higher production yield obtained during growth } \\
\text { on glycerol compared to cultivation on } \\
\text { hydrophobic carbon sources; Cell } \\
\text { hydrophobicity decreased during growth on } \\
\text { both glycerol and hexadecane; Production of } \\
\text { rhamnolipid was stimulated by nitrogen } \\
\text { limitation }\end{array}$ & $\begin{array}{l}\text { Arino et al. } \\
\text { (1996) }\end{array}$ \\
\hline
\end{tabular}


Table 1 continued

\begin{tabular}{|c|c|c|c|c|}
\hline Category & Year & Outline & Main conclusions & Reference \\
\hline Production & 1997 & $\begin{array}{l}\text { Rhamnolipids yield influenced by the type } \\
\text { of carbon source used }\end{array}$ & $\begin{array}{l}\text { Highest rhamnolipids yield achieved during } \\
\text { cultivation on ethanol under nitrogen limitation } \\
\text { conditions }\end{array}$ & $\begin{array}{l}\text { Matsufuji } \\
\text { et al. (1997) }\end{array}$ \\
\hline Production & 2007 & $\begin{array}{l}\text { Secretion of rhamnolipids during growth } \\
\text { on polycyclic aromatic hydrocarbons }\end{array}$ & $\begin{array}{l}\text { Rhamnolipids were produced under iron- } \\
\text { limitation conditions on both naphthalene and } \\
\text { phenanthrene }\end{array}$ & $\begin{array}{l}\text { Déziel et al. } \\
\text { (1996) }\end{array}$ \\
\hline Production & 2007 & $\begin{array}{l}\text { Production of rhamnolipids with the use } \\
\text { of genetically modified organisms }\end{array}$ & $\begin{array}{l}\text { The genes responsible for the ability to produce } \\
\text { rhamnolipids were successfully transferred and } \\
\text { the properties of the biosurfactant were } \\
\text { maintained }\end{array}$ & $\begin{array}{l}\text { Wang et al. } \\
\text { (2007) }\end{array}$ \\
\hline Production & 2008 & $\begin{array}{l}\text { Biodegradation potential and rhamnolipids } \\
\text { production of hydrophilic and hydrophobic } \\
P \text {. aeruginosa strain variants }\end{array}$ & $\begin{array}{l}\text { Higher biodegradation observed for the variant } \\
\text { with higher cell hydrophobicity; The } \\
\text { production of rhamnolipids was exhibited only } \\
\text { by the hydrophilic variant }\end{array}$ & $\begin{array}{l}\text { Obuekwe } \\
\text { et al. (2008) }\end{array}$ \\
\hline Production & 2011 & $\begin{array}{l}\text { Influence of rhamnolipids on cell surface } \\
\text { properties }\end{array}$ & $\begin{array}{l}\text { Comparable profile of rhamnolipid congeners } \\
\text { obtained during growth on hydrophobic } \\
\text { (hexadecane) or hydrophilic (glucose) } \\
\text { substrates }\end{array}$ & $\begin{array}{l}\text { Górna et al. } \\
\text { (2011) }\end{array}$ \\
\hline Protective agents & 2003 & Anti-microbial activity of rhamnolipids & $\begin{array}{l}\text { Rhamnolipids exhibited anti-microbial activity } \\
\text { against several bacterial and fungal species }\end{array}$ & $\begin{array}{l}\text { Haba et al. } \\
(2003)\end{array}$ \\
\hline Protective agents & 2010 & Rhamnolipids as insecticidal agents & $\begin{array}{l}\text { Dirhamnolipids exhibited considerable } \\
\text { insecticidal activity against Myzus persicae }\end{array}$ & $\begin{array}{l}\text { Kim et al. } \\
\text { (2011) }\end{array}$ \\
\hline Regulation & 1994 & $\begin{array}{l}\text { Isolation of the rhlR gene responsible } \\
\text { for the ability to produce rhamnolipids }\end{array}$ & $\begin{array}{l}\text { RhlR-deficient mutants were unable to produce } \\
\text { rhamnolipids. The gene was responsible for the } \\
\text { restoration of rhamnolipid biosynthesis and } \\
\text { ability to grow on hexadecane }\end{array}$ & $\begin{array}{l}\text { Ochsner et al. } \\
\text { (1994) }\end{array}$ \\
\hline Regulation & 1995 & $\begin{array}{l}\text { Substances serving as regulators for the } \\
\text { biosynthesis of rhamnolipids } \\
\text { in } P \text {. aeruginosa }\end{array}$ & $\begin{array}{l}\text { RhlR was discovered as a regulatory protein for } \\
\text { rhamnolipid biosynthesis; the system was } \\
\text { induced by the presence of N-acyl-homoserine } \\
\text { lactones and was also connected with the } \\
\text { synthesis of elastase }\end{array}$ & $\begin{array}{l}\text { Ochsner and } \\
\text { Reiser } \\
(1995)\end{array}$ \\
\hline Regulation & 2001 & $\begin{array}{l}\text { Regulation of rhamnolipid synthesis } \\
\text { in } P \text {. aeruginosa cells }\end{array}$ & $\begin{array}{l}\text { The gene rhlC encoding rhamnosyltransferase } \\
\text { responsible for the synthesis of dirhamnolipids } \\
\text { was discovered }\end{array}$ & $\begin{array}{l}\text { Rahim et al. } \\
\text { (2001) }\end{array}$ \\
\hline Regulation & 2004 & $\begin{array}{l}\text { Impact of a regulatory protein RsmA } \\
\text { on the functioning of } P \text {. aeruginosa cells }\end{array}$ & $\begin{array}{l}\text { RsmA controlled niche colonizing behavior, } \\
\text { such as swarming motility, rhamnolipid } \\
\text { biosynthesis and lipase activity; rsmZ, a } \\
\text { regulatory RNA, was discovered as a regulator } \\
\text { with antagonizing effects }\end{array}$ & $\begin{array}{l}\text { Heurlier et al. } \\
\text { (2004) }\end{array}$ \\
\hline Regulation & 2007 & $\begin{array}{l}\mathrm{A} \operatorname{lgR} \text { as a protein regulating rhamnolipid } \\
\text { biosynthesis during biofilm formation }\end{array}$ & $\begin{array}{l}\text { AlgR, a protein connected with virulence, } \\
\text { repressed the quorum-sensing system } \\
\text { regulating rhamnolipid biosynthesis during } \\
\text { biofilm growth and was found to be involved in } \\
\text { bacterial motility shifts }\end{array}$ & $\begin{array}{l}\text { Morici et al. } \\
\text { (2007) }\end{array}$ \\
\hline Regulation & 2007 & $\begin{array}{l}\text { Influence of autotransporter protein EstA on } \\
\text { rhamnolipid production and cellular life } \\
\text { mode }\end{array}$ & $\begin{array}{l}\text { Overexpression of EstA contributed to an } \\
\text { increased production of rhamnolipids and } \\
\text { influenced both bacterial motility and the } \\
\text { ability to form bacterial biofilms }\end{array}$ & $\begin{array}{l}\text { Wilhelm } \\
\text { et al. (2007) }\end{array}$ \\
\hline Regulation & 2009 & $\begin{array}{l}\text { Production of rhamnolipid and the regulation } \\
\text { mechanisms in Burkholderia thailandensis }\end{array}$ & $\begin{array}{l}\text { The regulatory system responsible for } \\
\text { biosynthesis of rhamnolipids was discovered; } \\
\text { the obtained rhamnolipid congeners were } \\
\text { different in terms of structure and composition } \\
\text { compared to } P \text {. aeruginosa biosurfactants }\end{array}$ & $\begin{array}{l}\text { Dubeau et al. } \\
\text { (2009) }\end{array}$ \\
\hline Regulation & 2010 & $\begin{array}{l}\text { Effect of iron limitation on rhamnolipid } \\
\text { biosynthesis and shifts in bacterial life } \\
\text { mode }\end{array}$ & $\begin{array}{l}\text { Iron limitation contributed to changes in the } \\
\text { timing of rhamnolipid expression, which were } \\
\text { shifted to the initial stages of biofilm } \\
\text { formation; The shift resulted in increased } \\
\text { bacterial surface motility }\end{array}$ & $\begin{array}{l}\text { Glick et al. } \\
\quad(2010)\end{array}$ \\
\hline
\end{tabular}


Table 1 continued

\begin{tabular}{|c|c|c|c|c|}
\hline Category & Year & Outline & Main conclusions & Reference \\
\hline Virulence & 2009 & $\begin{array}{l}\text { Influence of rhamnolipids produced by } \\
P \text {. aeruginosa biofilms on } \\
\text { polymorphonuclear leukocytes }\end{array}$ & $\begin{array}{l}\text { Rhamnolipids caused necrotic death of } \\
\text { polymorphonuclear leukocytes and were } \\
\text { suggested as key protective agents } \\
\text { of } P \text {. aeruginosa biofilms }\end{array}$ & $\begin{array}{l}\text { Van Gennip } \\
\text { et al. (2009) }\end{array}$ \\
\hline Review & 1996 & $\begin{array}{l}\text { Biosynthesis, genetic regulation, production } \\
\text { and growth conditions }\end{array}$ & - & $\begin{array}{l}\text { Desai and } \\
\text { Banat } \\
(1997)\end{array}$ \\
\hline Review & 1996 & $\begin{array}{l}\text { Biosynthesis, functions and influence on } \\
\text { bacterial adhesion }\end{array}$ & - & Neu (1996) \\
\hline Review & 1999 & $\begin{array}{l}\text { Biosynthesis, genetic regulation, properties, } \\
\text { production conditions and applications }\end{array}$ & - & $\begin{array}{l}\text { Lang and } \\
\text { Wullbrandt } \\
\text { (1999) }\end{array}$ \\
\hline Review & 2000 & $\begin{array}{l}\text { Biosynthesis, genetic regulation and } \\
\text { applications }\end{array}$ & - & $\begin{array}{l}\text { Maier and } \\
\text { Soberón- } \\
\text { Chávez } \\
(2000)\end{array}$ \\
\hline Review & 2003 & $\begin{array}{l}\text { Influence of synthetic surfactants and } \\
\text { biosurfactants on the degradation efficiency } \\
\text { of several hydrocarbons }\end{array}$ & - & $\begin{array}{l}\text { Makkar and } \\
\text { Rockne } \\
(2003)\end{array}$ \\
\hline Review & 2005 & $\begin{array}{l}\text { Structures, biosynthesis and production } \\
\text { conditions }\end{array}$ & - & $\begin{array}{l}\text { Nitschke } \\
\text { et al. (2005) }\end{array}$ \\
\hline Review & 2005 & $\begin{array}{l}\text { Genetic regulation, environmental and } \\
\text { growth conditions and influence on cell } \\
\text { lifestyle }\end{array}$ & - & $\begin{array}{l}\text { Soberón- } \\
\text { Chávez } \\
\text { et al. (2005) }\end{array}$ \\
\hline Review & 2010 & $\begin{array}{l}\text { Influence of rhamnolipids on microbial } \\
\text { motility, virulence and biofilm formation } \\
\text { processes; Regulation of bacterial behavior } \\
\text { as a response to various environmental } \\
\text { conditions }\end{array}$ & - & $\begin{array}{l}\text { Verstraeten } \\
\text { et al. (2008) }\end{array}$ \\
\hline Review & 2010 & $\begin{array}{l}\text { Role of rhamnolipids as anti-microbial agents } \\
\text { and immunity stimulators; anti-microbial } \\
\text { effect against numerous microorganisms } \\
\text { and potential applications }\end{array}$ & - & $\begin{array}{l}\text { Vatsa et al. } \\
(2010)\end{array}$ \\
\hline Review & 2010 & $\begin{array}{l}\text { Producers, structures, biosynthesis, growth } \\
\text { conditions and potential applications }\end{array}$ & - & $\begin{array}{l}\text { Abdel- } \\
\text { Mawgoud } \\
\text { et al. (2010) }\end{array}$ \\
\hline Review & 2011 & $\begin{array}{l}\text { Influence of rhamnolipids on biodegradation } \\
\text { of PAHs, potential producers and } \\
\text { rhamnolipid types }\end{array}$ & - & $\begin{array}{l}\text { Fernández- } \\
\text { Luqueño } \\
\text { et al. (2011) }\end{array}$ \\
\hline
\end{tabular}

combined efforts of many scientists over several decades. In the light of the most recent studies, rhamnolipids should be regarded as a multifunctional part of a mechanism which controls the fundamental elements of microbial life. The details behind this mechanism are becoming more and more apparent with each successive scientific report. Future studies, focused on gaining a better understanding of the principles of microbial world, will surely bring about several new potential applications for rhamnolipids.

Acknowledgments This manuscript was inspired by our previous work published in a polish journal Postępy Mikrobiologii. We are thankful to the editor of Postepy Mikrobiologii for supporting our idea to emphasize the impact of rhamnolipids on microbial life and review the multiple roles of this biosurfactant.
Open Access This article is distributed under the terms of the Creative Commons Attribution Noncommercial License which permits any noncommercial use, distribution, and reproduction in any medium, provided the original author(s) and source are credited.

\section{References}

Abdel-Mawgoud AM, Lépine F, Déziel E (2010) Rhamnolipids: diversity of structures, microbial origins and roles. Appl Microbiol Biotechnol 86:1323-1336

Allison DG, Ruiz B, San Jose C, Jaspe A, Gilbert P (1998) Extracellular products as mediators of the formation and detachment of Pseudomonas fluorescens biofilms. FEMS Microbiol Lett 167:179-184 
Al-Tahhan RA, Sandrin TR, Bodour AA, Maier RM (2000) Rhamnolipid-induced removal of lipopolysaccharide from Pseudomonas aeruginosa: effect on cell surface properties and interaction with hydrophobic substrates. Appl Environ Microbiol 66:3262-3268

Arino S, Marchal R, Vandecasteele JP (1996) Identification and production of a rhamnolipidic biosurfactant by a Pseudomonas species. Appl Microbiol Biotechnol 45:162-168

Arino S, Marchal R, Vandecasteele JP (2008) Involvement of a rhamnolipid-producing strain of Pseudomonas aeruginosa in the degradation of polycyclic aromatic hydrocarbons by a bacterial community. J Appl Microbiol 84:769-776

Beal R, Betts WB (2000) Role of rhamnolipid biosurfactants in the uptake and mineralization of hexadecane in Pseudomonas aeruginosa. J Appl Microbiol 89:158-168

Bergmans DC, Bonten MJ, Stobberingh EE, van Tiel FH, van der Geest S, de Leeuw PW, Gaillard CA (1998) Colonization with Pseudomonas aeruginosa in patients developing ventilatorassociated pneumonia. Infect Control Hosp Epidemiol 19: 853-855

Boles BR, Thoendel M, Singh PK (2004) Self-generated diversity produces 'insurance effects' in biofilm communities. Proc Natl Acad Sci USA 101:16630-16635

Boles BR, Thoendel M, Singh PK (2005) Rhamnolipids mediate detachment of Pseudomonas aeruginosa from biofilms. Mol Microbiol 57:1210-1223

Bouchez M, Blanchet D, Vandecasteele JP (1997) An interfacial uptake mechanism for the degradation of pyrene by a Rhodococcus strain. Microbiology 143:1087-1093

Bouchez-Naïtali M, Rakatozafy H, Marchal R, Leveau JY, Vandecasteele JP (1999) Diversity of bacterial strains degrading hexadecane in relation to the mode of substrate uptake. J Appl Microbiol 86:421-428

Boulton CA, Ratledge C (1984) The physiology of hydrocarbonutilizing microorganisms. In: Wieseman A (ed) Enzyme and fermentation biotechnology. Halstead Press, Wiley, New York, pp 11-77

Caiazza NC, Shanks RM, O’Toole GA (2005) Rhamnolipids modulate swarming motility patterns of Pseudomonas aeruginosa. J Bacteriol 187:7351-7361

Chrzanowski L, Kaczorek E, Olszanowski A (2005) Relation between Candida maltosa hydrophobicity and hydrocarbon biodegradation. World J Microbiol Biotechnol 21:1273-1277

Chrzanowski L, Kaczorek E, Olszanowski A (2006a) The Ability of Candida maltosa for hydrocarbon and emulsified hydrocarbon degradation. Pol J Environ Stud 15:47-51

Chrzanowski L, Kaczorek E, Pijanowska E, Olszanowski A (2006b) The relation between rhamnolipid adsorption on yeast and bacterial strains, hydrophobicity and hydrocarbon biodegradation. Fresen Environ Bull 15:682-686

Chrzanowski L, Bielicka-Daszkiewicz K, Owsianiak M, Aurich A, Kaczorek E, Olszanowski A (2008) Phenol and n-alkanes $\left(C_{12}\right.$ and $\mathrm{C}_{16}$ ) utilization: influence on yeast cell surface hydrophobicity. World J Microbiol Biotechnol 24:1943-1949

Chrzanowski L, Stasiewicz M, Owsianiak M, Szulc A, PiotrowskaCyplik A, Olejnik-Schmidt AK, Wyrwas B (2009a) Biodegradation of diesel fuel by a microbial consortium in the presence of 1-alkoxymethyl-2-methyl-5-hydroxypyridinium chloride homologues. Biodegradation 20:661-671

Chrzanowski L, Owsianiak M, Wyrwas B, Aurich A, Szulc A, Olszanowski A (2009b) Adsorption of sodium dodecylbenzenesulphonate (SDBS) on Candida maltosa EH 15 strain: influence on cell surface hydrophobicity and n-alkanes biodegradation. Water Air Soil Pollut 196:345-353

Chrzanowski L, Wick LY, Meulenkamp R, Kaestner M, Heipieper HJ (2009c) Rhamnolipid biosurfactants decrease the toxicity of chlorinated phenols to Pseudomonas putida DOT-T1E. Lett Appl Microbiol 48:756-762

Chrzanowski L, Owsianiak M, Szulc A, Marecik R, PiotrowskaCyplik A, Olejnik-Schmidt AK, Staniewski J, Lisiecki P, Ciesielczyk F, Jesionowski T, Heipieper HJ (2011) Interactions between rhamnolipid biosurfactants and toxic chlorinated phenols enhance biodegradation of a model hydrocarbon-rich effluent. Int Biodeter Biodegr 65(4):605-611

Cooper DG (1984) In: Ratledge C, Dawson P, Ra J (eds) Unusual aspects of biosurfactant production. Biotechnolgy for oils and fat industry. American Oil Chemists Society, Illinois, pp 281-287

Costerton JW, Stewart PS, Greenberg EP (1999) Bacterial biofilms: a common cause of persistent infections. Science 284:1318-1322

Czaczyk K, Białas W, Myszka K (2008) Cell surface hydrophobicity of Bacillus spp. as a function of nutrient supply and lipopeptides biosynthesis and its role in adhesion. Pol J Microbiol 57: 313-319

Dai Z, Wang Z, Xu JH, Qi H (2010) Assessing bioavailability of the solubilization of organic compound in nonionic surfactant micelles by dose-response analysis. Appl Microbiol Biotechnol 88(1):327-339

Darzins A (1994) Characterization of a Pseudomonas aeruginosa gene cluster involved in pilus biosynthesis and twitching motility: sequence similarity to the chemotaxis proteins of enterics and the gliding bacterium Myxococcus xanthus. Mol Microbiol 11:137-153

Davey ME, O'Toole GA (2000) Microbial biofilms: from ecology to molecular genetics. Microbiol Mol Biol Rev 64:847-867

Davey ME, Caiazza NC, O'Toole GA (2003) Rhamnolipid surfactant production affects biofilm architecture in Pseudomonas aeruginosa PAO1. J Bacteriol 185:1027-1036

Desai JD, Banat IM (1997) Microbial production of surfactants and their commercial potential. Microbiol Mol Biol Rev 61:47-64

Déziel E, Paquette G, Villemur R, Lépine F, Bisaillon JG (1996) Biosurfactant production by a soil Pseudomonas strain growing on polycyclic aromatic hydrocarbons. Appl Environ Microbiol 62:1908-1912

Déziel E, Comeau Y, Villemur R (2001) Initiation of biofilm formation by Pseudomonas aeruginosa 57RP correlates with the emergence of hyperpiliated and highly adherent phenotypic variants deficient in swimming, swarming and twitching motilities. J Bacteriol 183:1195-1204

Déziel E, Lépine F, Milot S, Villemur R (2003) RhlA is required for the production of a novel biosurfactant promoting swarming motility in Pseudomonas aeruginosa: 3-(3-hydroxyalkanoyloxy)alkanoic acids (HAAs), the precursors of rhamnolipids. Microbiology 149:2005-2013

Dubeau D, Déziel E, Woods D, Lépine F (2009) Burkholderia thailandensis harbors two identical $r h l$ gene clusters responsible for the biosynthesis of rhamnolipids. BMC Microbiol 9(263): $1-12$

Espinosa-Urgel M (2003) Resident parking only: rhamnolipids maintain fluid channels in biofilms. J Bacteriol 185:699-700

Espinosa-Urgel M, Salido A, Ramos JL (2000) Genetic analysis of functions involved in adhesion of Pseudomonas putida to seeds. J Bacteriol 182:2363-2369

Falatko DF, Novak JT (1992) Effects of biologically produced surfactants on the mobility and biodegradation of petroleum hydrocarbons. Water Environ Res 64:163-169

Fernández-Luqueño F, Valenzuela-Encinas C, Marsch R, MartínezSuárez C, Vázquez-Núñez E, Dendooven L (2011) Microbial communities to mitigate contamination of PAHs in soil-possibilities and challenges: A review. Environ Sci Pollut R 18(1): 12-30

Finnerty W (1994) Biosurfactants in environmental biotechnology. Curr Opin Biotechnol 5:291-295 
Fraser GM, Hughes C (1999) Swarming motility. Curr Opin Microbiol 2:630-635

Friedman L, Kolter R (2004) Two genetic loci produce distinct carbohydrate-rich structural components of the Pseudomonas aeruginosa biofilm matrix. J Bacteriol 186:4457-4465

Girón JA, Torres AG, Freer E, Kaper JB (2002) The flagella of enteropathogenic Escherichia coli mediate adherence to epithelial cells. Mol Microbiol 44:361-379

Glick R, Gilmour C, Tremblay J, Satanower S, Avidan O, Déziel E, Greenberg EP, Poole K, Banin E (2010) Increase in rhamnolipid synthesis under iron-limiting conditions influences surface motility and biofilm formation in Pseudomonas aeruginosa. J Bacteriol 192:2973-2980

Goldflam M, Rowe JJ (1983) Evidence for gene sharing in the nitrate reduction systems of Pseudomonas aeruginosa. J Bacteriol 155:1446-1449

Goodman AL, Kulasekara B, Rietsch A, Boyd D, Smith RS, Lory S (2004) A signaling network reciprocally regulates genes associated with acute infection and chronic persistence in Pseudomonas aeruginosa. Dev Cell 7:745-754

Górna H, Ławniczak Ł, Zgoła-Grześkowiak A, Kaczorek E (2011) Differences and dynamic changes in the cell surface properties of three Pseudomonas aeruginosa strains isolated from petroleum-polluted soil as a response to various carbon sources and the external addition of rhamnolipids. Biores Technol 102(3): 3028-3033

Guerra-Santos L, Kappeli O, Fiechter A (1984) Pseudomonas aeruginosa biosurfactant production in continuous culture with glucose as carbon source. Appl Microbiol Biotechnol 48:301-305

Guerra-Santos L, Kappeli O, Fiechter A (1986) Dependence of Pseudomonas aeruginosa continuous culture biosurfactant production on nutritional and environmental factors. Appl Microbiol Biotechnol 24:443-448

Haba E, Pinazo A, Jauregui O, Espuny MJ, Infante MR, Manresa A (2003) Physicochemical characterization and antimicrobial properties of rhamnolipids produced by Pseudomonas aeruginosa 47T2 NCBIM 40044. Biotechnol Bioeng 81:316-322

Hahn HP (1997) The type-4 pilus is the major virulence-associated adhesion of Pseudomonas aeruginosa-a review. Gene 192: 99-108

Hassett DJ, Ma JF, Elkins JG, McDermott TR, Ochsner UA, West SE (1999) Quorum sensing in Pseudomonas aeruginosa controls expression of catalase and superoxide dismutase genes and mediates biofilm susceptibility to hydrogen peroxide. Mol Microbiol 34:1082-1093

Hausner M, Wuertz S (1999) High rates of conjugation in bacterial biofilms as determined by quantitative in situ analysis. Appl Environ Microbiol 65:3710-3713

Heurlier K, Williams F, Heeb S, Dormond C, Pessi G, Singer D, Cámara M, Willias P, Haas D (2004) Positive control of swarming, rhamnolipid synthesis and lipase production by the posttranscriptional RsmA/RsmZ system in Pseudomonas aeruginosa PAO1. J Bacteriol 189:2936-2945

Hickman JW, Harwood CS (2008) Identification of FleQ from Pseudomonas aeruginosa as a c-di-GMP-responsive transcription factor. Mol Microbiol 69:376-389

Hickman JW, Tifrea DF, Harwood CS (2005) A chemosensory system that regulates biofilm formation through modulation of cyclic diguanylate levels. Proc Natl Acad Sci USA 102: 14422-14427

Hisatsuka KT, Nakahara T, Sano N, Yamada K (1971) Formation of rhamnolipid by Pseudomonas aeruginosa and its function in hydrocarbon fermentation. Agric Biol Chem 35:686-692

Hobbs M, Collie ES, Free PD, Livingston SP, Mattick JS (1993) PilS and PilR, a two-component transcriptional regulatory system controlling expression of type 4 fimbriae in Pseudomonas aeruginosa. Mol Microbiol 7:669-682

Hommel RK (1994) Formation and function of biosurfactants for degradation of water-insoluble substrates. In: Ratledge C (ed) Biochemistry of Microbial Biodegradationed. Kluwer Academic Publishers, Dordrecht, pp 63-87

Humphries M, Jaworzyn F, Cantwell JB (1986) The effectof a range of biological polymers, synthetic surfactants on the adhesion of marine Pseudomonas sp. strain NCMB 2021 to hydrophilic and hydrophobic surfaces. FEMS Microbiol Lett 38:299-308

Hunt SM, Werner EM, Huang B, Hamilton MA, Stewart PS (2004) Hypothesis for the role of nutrient starvation in biofilm detachment. Appl Environ Microbiol 70:7418-7425

Irie Y, O‘Toole GA, Yuk MH (2005) Pseudomonas aeruginosa rhamnolipids disperse Bordetella bronchiseptica biofilms. FEMS Microbiol Lett 250:237-243

Ishimoto KS, Lory S (1989) Formation of pilin in Pseudomonas aeruginosa requires the alternative sigma factor $(\mathrm{RpoN})$ of RNA polymerase. Proc Natl Acad Sci USA 86:1954-1957

Jain DK, Lee H, Trevors JT (1992) Effect of addition of Pseudomonas aeruginosa UG2 inocula or biosurfactants on biodegradation of selected hydrocarbons in soil. J Ind Microbiol 10:87-93

Jenal U, Malone J (2006) Mechanisms of cyclic-di-GMP signaling in bacteria. Annu Rev Genet 40:385-407

Johnsen AR, Karlson U (2004) Evaluation of bacterial strategies to promote the bioavailability of polycyclic aromatic hydrocarbons (PAHs). Appl Microbiol Biot 63:452-459

Johnsen AR, Wick LY, Harms H (2005) Principles of microbial PAHdegradation in soil. Environ Pollut 133:71-84

Kaczorek E, Chrzanowski Ł, Pijanowska A, Olszanowski A (2008) Yeast and bacteria cell hydrophobicity and hydrocarbon biodegradation in the presence of natural surfactants Rhamnolipides and saponins. Biores Technol 99:4285-4291

Kim SK, Kim YC, Lee S, Kim JC, Yun MY, Kim IS (2011) Insecticidal activity of rhamnolipid isolated from Pseudomonas sp. EP-3 against green peach aphid (Myzus persicae). J Agric Food Chem 59(3):934-938

Koch AK, Käppeli O, Feichter A, Reiser J (1991) Hydrocarbon assimilation and biosurfactant production in Pseudomonas aeruginosa mutants. J Bacteriol 173:4212-4219

Köhler T, Curty LK, Barja F, Van Delden C, Pechére JC (2000) Swarming of Pseudomonas aeruginosa is dependent on cell-tocell signaling and requires flagella and pili. J Bacteriol 182:5990-5996

Kuchma SL, Connolly JP, O'Toole GA (2005) A three-component regulatory system regulates biofilm maturation and type III secretion in Pseudomonas aeruginosa. J Bacteriol 187: 1441-1454

Kuchma SL, Brothers KM, Merritt JH, Liberati NT, Ausubel FM, O'Toole GA (2007) BifA, a cyclic-Di-GMP phosphodiesterase, inversely regulates biofilm formation and swarming motility by Pseudomonas aeruginosa PA14. J Bacteriol 189:8165-8178

Kulasekara HD, Ventre I, Kulasekara BR, Lazdunski A, Filloux A, Lory S (2005) A novel two-component system controls the expression of Pseudomonas aeruginosa fimbrial cup genes. Mol Microbiol 55:368-380

Lang S, Wullbrandt D (1999) Rhamnose lipids-biosynthesis, microbial production and application potential. Appl Microbiol Biotechnol 51:22-32

Lequette Y, Greenberg EP (2005) Timing and localization of rhamnolipid synthesis gene expression in Pseudomonas aeruginosa biofilms. J Bacteriol 187:37-44

Maier RM, Soberón-Chávez G (2000) Pseudomonas aeruginosa rhamnolipids: biosynthesis and potential applications. Appl Microbiol Biotechnol 54:625-633 
Makkar RS, Rockne KJ (2003) Comparison of synthetic surfactants and biosurfactants in enhancing biodegradation of polycyclic aromatic hydrocarbons. Environ Toxicol Chem 22:2280-2292

Manresa MA, Bastida J, Mercade ME, Robert M, de Andres C, Espuny MJ, Guinea J (1991) Kinetic studies on surfactant production by Pseudomonas aeruginosa 44T1. J Ind Microbiol 8:133-136

Mata-Sandoval J, Karns J, Torrents A (1999) High-performance liquid chromatography method for the characterization of rhamnolipid mixtures produced by Pseudomonas aeruginosa UG2 on corn oil. J Chromatogr A 864:211-220

Matsufuji M, Nakata K, Yoshimoto A (1997) High production of rhamnolipids by Pseudomonas aeruginosa growing on ethanol. Biotechnol Lett 9:1213-1215

Meadows PS (1971) The attachment of bacteria to solid surfaces. Arch Microbiol 75:374-381

Merritt JH, Brothers KM, Kuchma SL, O'Toole GA (2007) SadC reciprocally influences biofilm formation and swarming motility via modulation of exopolysaccharide production and flagellar function. J Bacteriol 189:8154-8164

Miller RM (1995) Surfactant-enhanced bioavailability of slightly soluble organic compounds. In: Skipper HD, Turco RF (eds) Bioremediation: science and applications. Soil Science Society of America, Madison, pp 322-354

Morici LA, Carterson AJ, Wagner VE, Frisk A, Schurr JR, zu Bentrup KH, Hassett DJ, Iglewski BH, Sauer K, Schurr MJ (2007) Pseudomonas aeruginosa $\mathrm{AlgR}$ represses the Rhl quorumsensing system in a Biofilm-specific manner. J Bacteriol 189:7752-7764

Mulligan CN, Gibbs BF (1989) Correlation of nitrogen metabolism with biosurfactant production by Pseudomonas aeruginosa. Appl Environ Microbiol 55:3016-3019

Mulligan CN, Mahmourides G, Gibbs BF (1989) The influence of phosphate metabolism on biosurfactant production by Pseudomonas aeruginosa. J Biotechnol 12:199-209

Myszka K, Czaczyk K (2009) Characterization of adhesive exopolysaccharide (EPS) produced by Pseudomonas aeruginosa under starvation conditions. Curr Microbiol 58:541-546

Myszka K, Czaczyk K, Shmidt MT, Olejnik AM (2007) Cell surface properties as factors involved in Proteus vulgaris adhesion to stainless steel under starvation conditions. World J Microbiol Biotechnol 23:1605-1612

Neu TR (1996) Significance of bacterial surface-active compounds in interaction of bacteria with interfaces. Microbiol Rev 60:151-166

Nitschke M, Costa S, Contiero J (2005) Rhamnolipid surfactants: an update on the general aspects of these remarkable biomolecules. Biotechnol Prog 21:1593-1600

Noordman WH, Janssen DB (2002) Rhamnolipid stimulates uptake of hydrophobic compounds by Pseudomonas aeruginosa. Appl Environ Microbiol 68:4502-4508

O'Toole GA, Kolter R (1998) Flagellar and twitching motility are necessary for Pseudomonas aeruginosa biofilm development. Mol Microbiol 30:295-304

O'Toole G, Kaplan HB, Kolter R (2000) Biofilm formation as microbial development. Annu Rev Microbiol 54:49-79

Oberbremer A, Müller-Hurtig R, Wagner F (1990) Effect of the addition of microbial surfactants on hydrocarbon degradation in a soil population in a stirred reactor. Appl Microbiol Biotechnol 32:485-489

Obuekwe CO, Al-Jadi ZK, Al-Saleh ES (2007) Insight into heterogeneity in cell-surface hydrophobocity and ability to degrade hydrocarbons among cells of two hydrocarbon-degrading bacterial populations. Can J Microbiol 53:252-260

Obuekwe CO, Al-Jadi ZK, Al-Saleh ES (2008) Comparative hydrocarbon utilization by hydrophobic and hydrophilic variants of Pseudomonas aeruginosa. J Appl Microbiol 105:1876-1887
Ochsner UA, Reiser J (1995) Autoinducer-mediated regulation of rhamnolipid biosurfactant synthesis in Pseudomonas aeruginosa. Proc Natl Acad Sci USA 92:6424-6428

Ochsner UA, Koch AK, Fiechter A, Reiser J (1994) Isolation and characterization of a regulatory gene affecting rhamnolipid biosurfactant synthesis in Pseudomonas aeruginosa. J Bacteriol 176:2044-2054

Owsianiak M, Chrzanowski L, Szulc A, Staniewski J, Olszanowski A, Olejnik-Schmidt AK, Heipieper HJ (2009a) Biodegradation of diesel/biodiesel blends by a consortium of hydrocarbon degraders: effect of the type of blend and the addition of biosurfactants. Biores Technol 100:1497-1500

Owsianiak M, Szulc A, Chrzanowski Ł, Cyplik P, Bogacki M, Olejnik-Schmidt AK, Heipieper HJ (2009b) Biodegradation and surfactant-mediated biodegradation of diesel fuel by 218 microbial consortia are not correlated to cell surface hydrophobicity. Appl Microbiol Biotechnol 84:545-553

Pamp SJ, Tolker-Nielsen T (2007) Multiple roles of biosurfactants in structural biofilm development by Pseudomonas aeruginosa. J Bacteriol 189:2531-2539

Parra JL, Pastor J, Comelles F, Manresa MA, Bosch MP (1990) Studies of biosurfactants obtained from olive oil. Tenside Surfact Det 27:302-306

Parsek MR, Greenberg EP (2000) Acyl-homoserine lactone quorum sensing in gram-negative bacteria: a signaling mechanism involved in associations with higher organisms. Proc Natl Acad Sci USA 97:8789-8793

Parsek MR, Singh PK (2003) Bacterial biofilms: an emerging link to disease pathogenesis. Annu Rev Microbiol 57:677-701

Prince RC (2005) The microbiology of marine spill bioremediation. In: Olivier B, Magot M (eds) Petroleum microbiology. ASM press, Washington, pp 35-54

Rahim R, Ochsner UA, Olvera C, Graninger M, Messner P, Lam JS, Soberon-Chavez G (2001) Cloning and functional characterization of the Pseudomonas aeruginosa rhlC gene that encodes rhamnosyltransferase 2, an enzyme responsible for dirhamnolipid biosynthesis. Mol Microbiol 40:708-718

Roberts NA, Gray GW, Wilkinson SG (1967) Release of lipopolysaccharide during the preparation of cell walls of Pseudomonas aeruginosa. Biochimi Biophys Acta Biomembr 135:1068-1071

Sauer K, Camper AK, Ehrlich GD, Costerton JW, Davies DG (2002) Pseudomonas aeruginosa displays multiple phenotypes during development as a biofilm. J Bacteriol 184:1140-1154

Schooling SR, Charaf UK, Allison DG, Gilbert G (2004) A role for rhamnolipid in biofilm dispersion. Biofilms 1:91-99

Shapiro JA (1998) Thinking about bacterial populations as multicellular organisms. Annu Rev Microbiol 52:81-104

Sharma M, Anand SK (2002) Swarming: a coordinated bacterial activity. Curr Sci 83:707-715

Singer ME, Finnerty WR (1984) Microbial metabolism of straightchain and branched alkanes. In: Atlas RM (ed) Microbial metabolism of straight-chain and branched alkanes. Macmillan Publish Comp., New York, pp 1-60

Soberón-Cháves G, Lépine F, Déziel E (2005) Production of rhamnolipids by Pseudomonas aeruginosa. Appl Microbiol Biotechnol 68:718-725

Soberón-Chávez G (2004) Biosynthesis of rhamnolipids. In: Ramos JL (ed) Pseudomonas. Kluwer Academic/Plenum Publishers, New York, pp 173-189

Stewart PS (2002) Mechanisms of antibiotic resistance in bacterial biofilms. Int J Med Microbiol 292:107-113

Stoodley P, Wilson S, Hall-Stoodley L, Boyle JD, Lappin-Scott HM, Costerton JW (2001) Growth and detachment of cell clusters from mature mixed-species biofilms. Appl Environ Microbiol 67:5608-5613 
Stoodley P, Cargo R, Rupp CJ, Wilson S, Klapper I (2002) Biofilm material properties as related to shear induced deformation and detachment phenomena. J Ind Microbiol Biotechnol 29:361-367

Taguchi K, Fukutomi H, Kuroda A, Kato J, Ohtake H (1997) Genetic identification of chemotactic transducers for amino acids in Pseudomonas aeruginosa. Microbiology 143:3223-3229

Thormann KM, Saville RM, Shukla S, Spormann AM (2005) Induction of rapid detachment in Shewanella oneidensis MR-1 biofilms. J Bacteriol 187:1014-1021

Tremblay J, Richardson AP, Lépine F, Déziel E (2007) Self-produced extracellular stimuli modulate the Pseudomonas aeruginosa swarming motility behavior. Environ Microbiol 9:2622-2630

Van Gennip M, Christensen LD, Alhede M, Phipps R, Jensen PO, Christophersen L, Pamp SJ, Moser C, Mikkelsen PJ, Koh AY, Tolker-Nielsen T, Pier GB, Hoiby N, Givskov M, Bjarnsholt T (2009) Inactivation of the rhlA gene in Pseudomonas aeruginosa prevents rhamnolipid production, disabling the protection against polymorphonuclear leukocytes. Apmis 117:537-546

Vatsa P, Sanchez L, Clement C, Baillieul F, Dorey S (2010) Rhamnolipid biosurfactants as new players in animal and plant defense against microbes. Int J Mol Sci 11(12):5095-5108

Ventre I, Goodman AL, Vallet-Gely I, Vasseur P, Soscia C, Molin S, Bleves S, Lazdunski A, Lory S, Filloux A (2006) Multiple sensors control reciprocal expression of Pseudomonas aeruginosa regulatory RNA and virulence genes. Proc Natl Acad Sci USA 103:171-176

Verstraeten N, Braeken K, Dabkurami B, Fauvart M, Fransaer J, Vermant J, Michiels J (2008) Living on a surface: swarming and biofilm formation. Trends Microbiol 16:496-506

Volkering FA, Breure M, Rulkens WH (1998) Microbiological aspects of surfactant use for biological soil remediation. Biodegradation 8:401-417

Wang Z (2011) Bioavailability of organic compounds solubilized in nonionic surfactant micelles. Appl Microbiol Biotechnol 89(3): 523-534

Wang Q, Fang X, Bai B, Liang X, Shuler PJ, Goddard WA III, Tang Y (2007) Engineering bacteria for production of rhamnolipid as an agent for enhanced oil recovery. Biotechnol Bioeng 98(4): $842-853$

Webb JS, Thompson LS, James S, Charlton T, Tolker-Nielsen T, Koch B (2003) Cell death in Pseudomonas aeruginosa biofilm development. J Bacteriol 185:4585-4592

Whitchurch CB, Hobbs M, Livingston SP, Krishnapillai V, Mattick JS (1991) Characterisation of a Pseudomonas aeruginosa twitching motility gene and evidence for a specialised protein export system widespread in eubacteria. Gene 101:33-44

Whiteley M, Bangera MG, Bumgarner RE, Parsek MR, Teitzel GM, Lory S, Greenberg EP (2001) Gene expression in Pseudomonas aeruginosa biofilms. Nature 413:860-864

Wilhelm S, Gdynia A, Tielen P, Rosenau F, Jaeger KE (2007) The autotransporter esterase EstA of Pseudomonas aeruginosa is required for rhamnolipid production, cell motility, and biofilm formation. J Bacteriol 189:6695-6703

Wolfe AJ, Visick KL (2008) Get the message out: cyclic-di-GMP regulates multiple levels of flagellum-based motility. J Bacteriol 190:463-475

Zeng G, Liu Z, Zhong H, Li J, Yuan X, Fu H, Ding Y, Wang J, Zhou M (2011) Effect of monorhamnolipid on the degradation of n-hexadecane by Candida tropicalis and the association with cell surface properties. Appl Microbiol Biotechnol 90(3):1155-1161

Zgoła-Grześkowiak A, Kaczorek E (2011) Isolation, preconcentration and determination of rhamnolipids in aqueous samples by dispersive liquid-liquid microextraction and liquid chromatography with tandem mass spectrometry. Talanta 83(3):744-750

Zhang Y, Miller RM (1992) Enhanced octadecane dispersion and biodegradation by a Pseudomonas rhamnolipid surfactant (biosurfactant). Appl Environ Microbiol 58:3276-3282

Zhang Y, Miller RM (1994) Effect of a Pseudomonas rhamnolipid biosurfactant on cell hydrophobicity and biodegradation of octadecane. Appl Environ Microbiol 60:2101-2106

Zhang Y, Miller RM (1995) Effect of rhamnolipid (biosufactant) structure on solubilization and biodegradation o n-alkanes. Appl Environ Microbiol 61:2247-2251 